\title{
A Stability Analysis Using AMMI and GGE Biplot Approach on Forage Yield Assessment of Common Vetch in Both Conventional and Low-Input Cultivation Systems
}

\author{
Vasileios Greveniotis ${ }^{1,2, *}$, Elisavet Bouloumpasi ${ }^{3}$, Stylianos Zotis ${ }^{2,+}{ }^{,}$, Athanasios Korkovelos ${ }^{4}$ \\ and Constantinos G. Ipsilandis 5 \\ 1 Hellenic Agricultural Organization Demeter, Institute of Industrial and Forage Crops, \\ GR-41335 Larissa, Greece \\ 2 Department of Agricultural Technology, Technological Educational Institute of Western Macedonia, \\ GR-53100 Florina, Greece \\ 3 Department of Agricultural Biotechnology and Oenology, International Hellenic University, \\ GR-66100 Drama, Greece; elisboul@abo.ihu.gr \\ 4 Directorate of Water Management of Thessaly, Decentralized Administration of Thessaly-Central Greece, \\ GR-41335 Larissa, Greece; athanasios.korkovelos@apdthest.gov.gr \\ 5 Regional Administration of Central Macedonia, Department of Agriculture, GR-54622 Thessaloniki, Greece; \\ ipsigene@gmail.com \\ * Correspondence: vgreveni@mail.com; Tel.: +30-241-067-1285 \\ + Deceased.
}

Citation: Greveniotis, V.;

Bouloumpasi, E.; Zotis, S.;

Korkovelos, A.; Ipsilandis, C.G. A

Stability Analysis Using AMMI and

GGE Biplot Approach on Forage

Yield Assessment of Common Vetch

in Both Conventional and Low-Input Cultivation Systems. Agriculture 2021, 11, 567. https://doi.org/10.3390/ agriculture11060567

Academic Editors: Panagiotis Madesis and Irini Nianiou-Obeidat

Received: 25 April 2021

Accepted: 16 June 2021

Published: 20 June 2021

Publisher's Note: MDPI stays neutral with regard to jurisdictional claims in published maps and institutional affiliations.

Copyright: () 2021 by the authors. Licensee MDPI, Basel, Switzerland. This article is an open access article distributed under the terms and conditions of the Creative Commons Attribution (CC BY) license (https:// creativecommons.org/licenses/by/ $4.0 /)$.

\begin{abstract}
Common vetch (Vicia sativa L.) is a widespread legume crop in the Mediterranean megaenvironment, due to its versatile uses and its compatibility with organic and low-input farming systems. However, its adaptation to various such environments should be studied and varieties suitable for forage yield must be selected. This study aimed to explore forage yield stability of common vetch varieties based on the stability index, with a specific target to explore common vetch variety behavior in various environments. Six Greek varieties of common vetch were used over four environments for two years. The cultivation was conducted using a strip plot with the varieties randomized within each plot in both conventional and low-input cultivation systems. (Alexandros) and (Tempi) varieties showed stability for days to $50 \%$ of flowering (index $>4000$ ), while (Pigasos) and (Zefyros) for fresh forage yield (>200) across environments. Combined estimations, also showed stability of (Pigasos) and (Zefyros) for fresh forage yield. Comparisons between the conventional and low-input farming systems generally showed minor differences but revealed varieties that exhibit stable performance even in the low-input farming systems, where stability is generally a little higher. The AMMI and GGE biplot analysis depicted the stability performance of the varieties regarding the traits under experimentation. As far as the fresh forage and dry matter yield, (Zefyros) was the most stable and productive variety over all others. Correlations between traits displayed the positive relation of fresh forage yield with days for $50 \%$ flowering and dry forage yield. Positive correlations may be proved useful for indirect breeding through traits with high stability leading to the selection of traits that show low stability.
\end{abstract}

Keywords: low-input; stability; indirect breeding; biplot analysis

\section{Introduction}

Common vetch (Vicia sativa ssp. sativa L.) is one of the most important livestock legumes in the Mediterranean mega-environment due to its multiple uses, its high nutritional value, and its ability to grow in different environmental conditions [1]. Turkey holds the first place regarding common vetch grain production among Mediterranean countries, followed by Spain, Italy, and Greece, while Greece is also fourth with regard to the harvested area in the Mediterranean basin [2]. According to official data, annual 
production in vetches was approximately 57,060 tons in 2017 , while the cultivated area was 31,977 ha [3].

Increased nutritional needs for livestock require the introduction of animal feed legumes in crop rotations [4]. Common vetch is considered among the best options to be part of crop rotations, especially in lower rainfall areas, and a good alternative to cereal monoculture, as it produces higher seed and protein yields, in comparison [5]. Another advantage of vetch cultivations is their compatibility with organic and low-input farming systems. Its usefulness is based on the exploitation of atmospheric nitrogen yielding satisfactory in certain cultivation areas [6]. Vetch-cereal intercrops produce considerably higher protein yields on the soil without any need for N-fertilizers. It is a usual approach to cultivate local varieties or mixtures among them, to maintain yield under low-input farming systems that support mainly livestock [7].

Climate change is a challenge to ensuring food and feed for the increasing population in the 21st century. Various climatic environments require varieties with good and stable performance to ensure production [8]. On the other hand, the adoption of organic farming principles under low-input conditions requires also the use of proper genetic materials to ensure stability $[7,9]$. Stability is a difficult target for both breeders and farmers that have to cope with the specific adaptability of varieties [10,11]. Ecological processes are combined with biodiversity, low inputs, and adapted cultivation cycles in local conditions. Appropriate varieties for forage yield must be selected based on adaptation in various, and especially low-input, environments and, therefore, extensive experimentation is needed both by breeders and agronomists. In faba beans, biomass yield, seed yield, and yield components were studied together with plant height, earliness, and water use efficiency [12]. Both genotype, environment, and also their interaction affected the studied characteristics. The environment was the major source of variation, while genotype displayed a much smaller effect. GGE-biplot analysis for high yield and stability across different environments revealed three genotypic types: (a) well adapted either for biomass, (b) seed yield, and (c) with high adaptation ability for both traits. Fasahat et al. [13], summarized the concept Genotype $x$ Environment interactions, for breeding purposes in various crops, to facilitate the choice of breeders to select the appropriate method.

A recent work summarized stability parameters, especially for long-term field experiments [14]. The authors suggest that relative surveys and research works must include:

(i) data quality and methodological approaches in the analysis of yield stability that are as transparent as possible,

(ii) testing for and deal with outliers,

(iii) investigation on potentially confounding factors in the statistical model,

(iv) exploratory pathways on the need for detrending of yield data,

(v) account for temporal autocorrelation,

(vi) the choice for the stability measures and consider the correlation between some of the measures,

(vii) consideration on the dependence of stability measures on the mean yield,

(viii) temporal trends of stability, and

(ix) reports on standard errors and statistical inference of stability measures where possible.

AMMI model is a hybrid model that combines analysis of variance (ANOVA) and principal component analysis (PCA) [15,16]. GGE biplot clearly visualizes interactions and cross-impact between genotypes, environments, and total interaction [17].

The main aim of the present work was to explore forage yield stability of common vetch varieties based on stability index, with a specific target to investigate common vetch variety behavior in various environments. Our novel approach is based on the principles described by Fasoulas [18], regarding stability parameters of genotypes and also on the stability index as described and applied by Fasoula [19]. Greveniotis et al., [20], used successfully a trait stability index to describe the type of trait inheritance in cotton and to depict the varieties better adapted in certain environments. 


\section{Materials and Methods}

\subsection{Crop Establishment and Experimental Procedures}

Field experiments were conducted during two growing seasons (2010-2011 and 20112012) in four different locations. Two locations in Northern Greece and two locations in Central Greece were selected, varying in soil type and altitude. Coordinates according to the WGS 1984 geographic coordinate system are provided.

(A) InGiannitsa, Northern Greece (latitude, $40^{\circ} 77^{\prime} \mathrm{N}$;longitude, $22^{\circ} 39^{\prime}$ E; elevation, $10 \mathrm{~m}$ a.s.1.). The soil type was clay (C): sand, $9.1 \%$; silt, $37.5 \%$; clay, $53.8 \%$. The chemical properties of the soil were as follows: conventional: $\mathrm{N}-\mathrm{NO}_{3}, 15.1 \mathrm{mg} \mathrm{kg}{ }^{-1}$; P-Olsen, $17.4 \mathrm{mg} \mathrm{kg}^{-1} ; \mathrm{K}, 274 \mathrm{mg} \mathrm{kg}^{-1}$; $\mathrm{pH}_{\mathrm{H} 20}, 7.69$; organic matter, $3.26 \%$; and $\mathrm{CaCO}_{3}, 5.23(\%)$.Low-input system: $\mathrm{N}^{-N_{3}}, 16.1 \mathrm{mg} \mathrm{kg}^{-1}$; P-Olsen, $15.9 \mathrm{mg} \mathrm{kg}^{-1}$; $\mathrm{K}$, $261 \mathrm{mg} \mathrm{kg}^{-1} ; \mathrm{pH}_{\mathrm{H} 20}, 7.65$; organic matter, $3.51 \%$, and $\mathrm{CaCO}_{3}, 5.37(\%)$.

(B) In the farm of the Technological Educational Institute of Western Macedonia in Florina, northern Greece (latitude, $40^{\circ} 46^{\prime} \mathrm{N}$;longitude, $21^{\circ} 22^{\prime}$ E;elevation, $705 \mathrm{~m}$ a.s.l.). The soil type was characterized as a sandy loam (SL): sand, $62 \%$; silt, $26.9 \%$; clay, $11.1 \%$. The chemical properties of the soil were as follows: conventional: $\mathrm{N}^{-N_{3}}, 16.1 \mathrm{mg} \mathrm{kg}^{-1}$; P-Olsen, $26.4 \mathrm{mg} \mathrm{kg}^{-1}$; $\mathrm{K}, 236 \mathrm{mg} \mathrm{kg}^{-1}$; $\mathrm{pH}_{\mathrm{H} 20}, 6.32$; organic matter, $1.29 \%$; and $\mathrm{CaCO}_{3}, 1.7(\%)$. Low-input system: ${\mathrm{N}-\mathrm{NO}_{3}}_{3}, 17.4 \mathrm{mg} \mathrm{kg}^{-1}$; P-Olsen, $25.1 \mathrm{mg} \mathrm{kg}^{-1}$; $\mathrm{K}$, $224 \mathrm{mg} \mathrm{kg}^{-1} ; \mathrm{pH}_{\mathrm{H} 20}, 6,29$; organic matter, $1.32 \%$, and $\mathrm{CaCO}_{3}, 1.9(\%)$.

(C) In Trikala, Central, Greece (latitude, $39^{\circ} 55^{\prime} \mathrm{N}$; longitude, $21^{\circ} 64^{\prime} \mathrm{E}$; elevation, $120 \mathrm{~m}$ a.s.l.). The soil type was characterized as sandy clay loam (SCL): sand, $48.6 \%$; silt, $19.2 \%$; clay, $32.2 \%$. The chemical properties of the soil were as follows: conventional: $\mathrm{N}-\mathrm{NO}_{3}, 12.7 \mathrm{mg} \mathrm{kg}^{-1}$; P-Olsen, $11.8 \mathrm{mg} \mathrm{kg}^{-1} ; \mathrm{K}, 168 \mathrm{mg} \mathrm{kg}^{-1} ; \mathrm{pH}_{\mathrm{H} 20}, 8.15$; organic

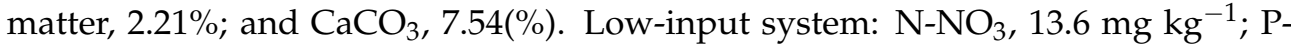
Olsen, $11.5 \mathrm{mg} \mathrm{kg}^{-1} ; \mathrm{K}, 176 \mathrm{mg} \mathrm{kg}^{-1} ; \mathrm{pH}_{\mathrm{H} 20}, 8.11$; organic matter, $2.39 \%$, and $\mathrm{CaCO}_{3}$, $7.63(\%)$.

(D) In Kalambaka, Central Greece (latitude, $39^{\circ} 64^{\prime} \mathrm{N}$;longitude, $21^{\circ} 65^{\prime}$ E;elevation, $190 \mathrm{~m}$ a.s.l.). The soil type was silty clay ( $\mathrm{SiC}$ ): sand, $14.6 \%$;silt, $41.2 \%$; clay, $44.2 \%$. The chemical properties of the soil were as follows: conventional: $\mathrm{N}^{-\mathrm{NO}_{3}}, 11.39 \mathrm{mg} \mathrm{kg}^{-1}$; P-Olsen, $7.62 \mathrm{mg} \mathrm{kg}^{-1} ; \mathrm{K}, 96.3 \mathrm{mg} \mathrm{kg}^{-1} ; \mathrm{pH}_{\mathrm{H} 20}, 8.05$; organic matter, $2.14 \%$; and $\mathrm{CaCO}_{3}, 3.58(\%)$. Low-input system: ${\mathrm{N}-\mathrm{NO}_{3}}_{3}, 12.01 \mathrm{mg} \mathrm{kg}^{-1}$; P-Olsen, $7.56 \mathrm{mg} \mathrm{kg}^{-1}$; $\mathrm{K}, 98.7 \mathrm{mg} \mathrm{kg}^{-1} ; \mathrm{pH}_{\mathrm{H} 20}, 8.08$; organic matter, $2.21 \%$, and $\mathrm{CaCO}_{3}, 3.65(\%)$.

Those locations were selected deliberately because of their varied environmental conditions. Basic weather data (mean monthly temperatures in ${ }^{\circ} \mathrm{C}$ and rainfall in $\mathrm{mm}$ ) for each experimental site based on daily records, for the two growing seasons of the experimentation, are given in Figure 1.

Common vetch (Vicia sativa L.) varieties well established in Greece were selected for cultivation using a strip-plot design with the six varieties (namely cv. (Alexandros), cv. (Filippos), cv. (Omiros), cv. (Pigasos), cv. (Tempi), and cv. (Zefyros). The characteristics of the selected varieties are given next [21].

(Alexandros) was developed in Greece. It is very stable and well adapted to Greek environments. This variety is characterized by high hay yield, has early flowering, and is suited for green manure. It develops rich fresh forage, although its development in early stages is slow. It yields hay $4000-6500 \mathrm{~kg} \mathrm{ha}^{-1}$ and grain $1500-2200 \mathrm{~kg} \mathrm{ha}^{-1}$.

(Filippos) was bred in Greece, it is characterized by high hay yield, with high protein content, also could be used for silage. It is sown mainly in autumn.

(Omiros) was developed in Greece and is well adapted to Greek environments. It is very productive. The advantage (Omiros) has over other varieties is its winter growth and vigor combined with good frost tolerance (can withstand the cold up to $-10{ }^{\circ} \mathrm{C}$ ). It is suitable as green manure. It provides rich hay with a high content of pods and a high yield in seed. The protein content of the seed ranges from $22 \%$ to $27 \%$ and provides a good source of energy and phosphorus for livestock fodder. 
Giannitsa

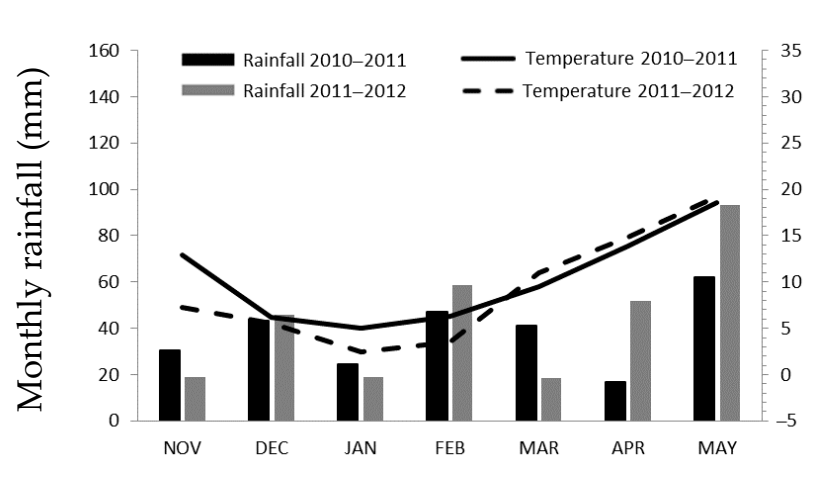

Trikala

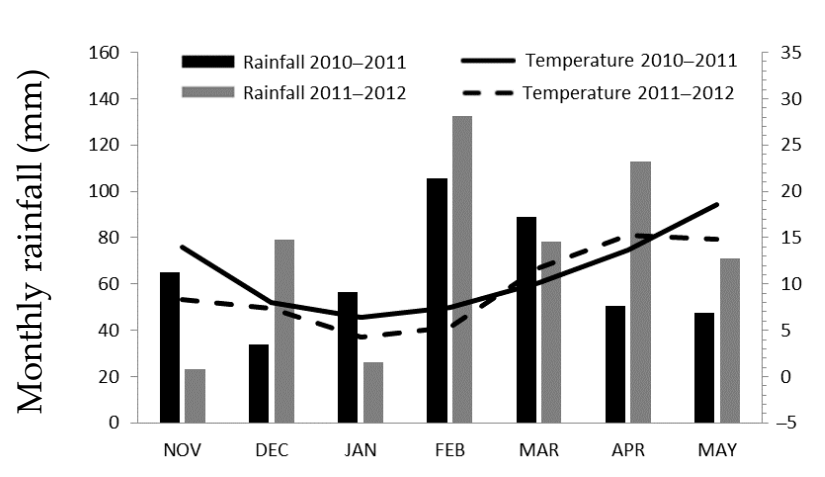

Florina

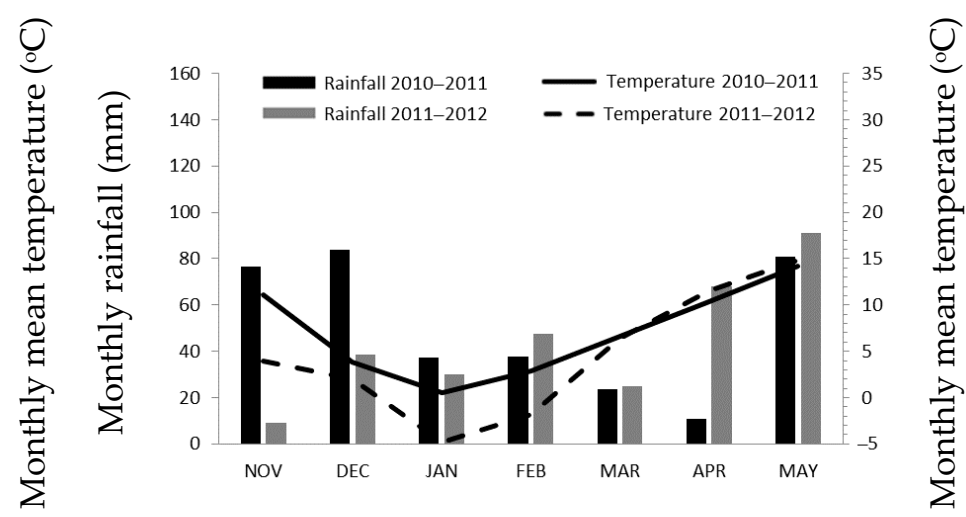

Kalambaka
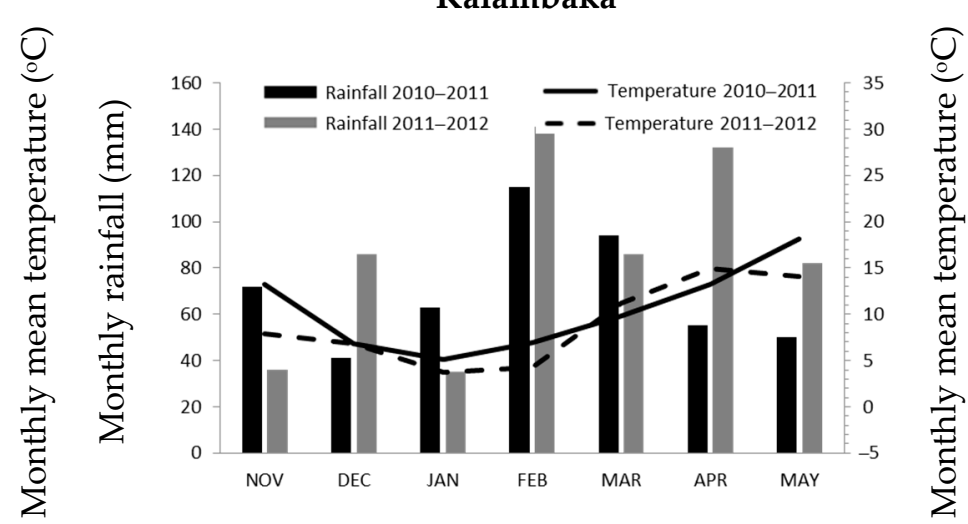

Figure 1. Basic weather data (mean monthly temperature in ${ }^{\circ} \mathrm{C}$ and rainfall in $\mathrm{mm}$ ) based on daily records, through two growing seasons.

(Pigasos) was developed in Greece for hay and grain production. It is well adapted to all environments, and well resistant to drought. It is characterized by the good early establishment, is categorized in early to mid-early varieties, and develops rich chloromass. It produces hay $4000-6000 \mathrm{~kg} \mathrm{ha}^{-1}$ and grain $1500-2000 \mathrm{~kg} \mathrm{ha}^{-1}$.

(Tempi) was developed in Greece for hay and grain production. It is well adapted to Greek environments and is adequately drought tolerant. It develops rich chloromass and is proposed for use as green manure, as well as mixed-planted with oats. It yields hay 4000-6000 kg ha ${ }^{-1}$ and grain 1500-2000 kg ha ${ }^{-1}$.

(Zefyros) was developed in Greece for hay production. It is well adapted to Greek environments and is adequately drought tolerant. It is categorized into mid-early varieties. It yields hay $4000-6500 \mathrm{~kg} \mathrm{ha}^{-1}$ and grain $1500-2200 \mathrm{~kg} \mathrm{ha}^{-1}$.

The selected varieties were installed randomized within each plot. Seven rows five meters long consisted of each plot, the distances between rows were $0.25 \mathrm{~m}$, with a total plot size amounting to $8.75 \mathrm{~m}^{2}$.

Low-input and conventional farming systems were applied. The plots cultivated under the conventional farming system were fertilized before sowing so that 30 and $50 \mathrm{~kg} \mathrm{ha}^{-1}$, Nitrogen and $\mathrm{P}_{2} \mathrm{O}_{5}$, respectively were added into the soil.

For low-input cultivation, no fertilizers or other agrochemicals were applied during the experiment in all four different locations, while prior to the establishment of the experiment in 2010, the fields had been in a two-year rotation consisting of bread wheat/legume without nutritional supplementation or other agrochemical inputs.

Weeds were controlled by hand in the experimental area. The selected varieties were sown in early November during November 2010 and November 2011 for growing seasons 
2010-2011 and 2011-2012, respectively, and were harvested in early May 2011 and May 2012 for growing seasons 2010-2011 and 2011-2012, respectively, upon reaching full flowering.

\subsection{Measurements}

Traits measured were:

1. Days to $50 \%$ flowering: This corresponds to the number of days passing from the sowing date to $50 \%$ of the flowering time; it was recorded for each plot [22].

2. Main stem length: Corresponds to the mean height of ten random plants of each plot, measured from ground level to the top point with a ruler ( $1 \mathrm{~mm}$ sensitivity) after extending the plants upward at flowering time. The arithmetic mean of the measurements was accepted as the main stem length for each plot.

3. The number of main stems per plant: This corresponds to the number of first stems accounted for from the bottom part of the plants in flowering time. The number occurred as an arithmetic mean of values obtained from ten plants of each plot, situated in different parts of the plot

4. Fresh forage yield $\left(\mathrm{kg} \mathrm{ha}^{-1}\right)$ : Corresponds to the weight of chloromass (fresh forage) obtained from each plot right after harvesting in full flowering time and subsequent calculation on a hectare basis.

5. Dry matter yield $\left(\mathrm{kg} \mathrm{ha}^{-1}\right)$ : Corresponds to the dry matter percent per plot calculated after fresh forage samples $(0.5 \mathrm{Kg})$, harvested from each experimental plot were placed at $70{ }^{\circ} \mathrm{C}$ for $48 \mathrm{~h}$ in a drying oven, left to cool, and weighed. Then, dry matter yield was determined for each plot, and the value was converted to a hectare basis.

6. Forage dry matter crude protein content (\%): Forage dry matter was passed through a $1 \mathrm{~mm}$ sieve and subsequently mixed for the analysis. Total $\mathrm{N}$ was determined using AOAC Official Method 988.05 [23] and then the total protein content was estimated.

7. Ash content (\%) of dry matter: Ash was analyzed using AOAC Official Method 942.05 [23].

\subsection{Data Analysis}

Data primarily analyzed via ANOVA over environments and cultivation practice to experience if there are significant differences for all traits investigated in this study. For the ANOVA table to be more informative the combination of each year and location was assigned as the environment. In this way, we have fewer interactions in the ANOVA table and do not affect the variance of Genotypes (varieties) and the $\mathrm{G} \times \mathrm{E}$ (Genotype $\times$ Environment) interaction which is crucial for proceeding in the stability analysis.

Stability index calculation $(\bar{x} / s)^{2}$, where $\bar{x}$ and $s$ are the entry mean yield (etc.) and standard deviation, respectively, was employed for stability estimations $[10,19]$. Pearson coefficient according to Steel et al. [24] was applied for trait correlations, and statistical significance of all data was checked at $p<0.05$ with SPSS ver. 25 statistical software. As a precondition, we took into account the suggestions of Reckling et al. [14]. For the computation of AMMI and (GGE) biplot analysis for interactions used the free version of PB Tools v1.4 (International Rice Research Institute, Laguna, Philippines).

The AMMI model is a widely used statistical tool in the analysis of multi-environment experiments. The purpose is to understand the complex GEI. In the AMMI model the data are represented by a two-way table of GEI means. In the complete tables, least squares estimation is equivalent to fitting an additive two-way ANOVA model for the main effects and applying a singular value decomposition to the interaction residuals [25].

Using this statistical tool AMMI software generates mainly the adaptation map and AMMI1 biplot where one axis is the axis of the factor and the other is the PC1 value. When the $\mathrm{PC} 1$ value and its distance from the $\mathrm{X}$-axis are close then the factor analyzed is stable. Regarding the AMMI1 biplot, the desirable varieties were those having high value on the axis of trait performance (x-axis, right position) and close to the center of the PC1 axis (near zero).

GGE stands for genotype main effect $(G)$ plus genotype by environment interaction (GE), which is the only source of variation that is relevant to cultivar evaluation. Mathe- 
matically, GGE is the genotype by environment data matrix after the environment means are subtracted.

A GGE biplot is a biplot that displays the GGE of a genotype by environment twoway data. The GGE biplot methodology originates from the graphical analysis of multienvironment variety trials (MET) data but is equally applicable to all other types of two-way data.

Regarding the GGE biplot for environments, the most stable environment was that placed close to the dot of ideal and average environment and in the concentric area of the ideal environment dot. As far as the GGE biplot for varieties, the desirable varieties (stable and productive) were those which placed near to the ideal variety and in the concentric area of the ideal variety dot.

\section{Results}

Regarding the ANOVA table, the main effects for all traits expressed significant differences. Furthermore, the $\mathrm{G} \times \mathrm{E}$ (varieties $\times$ environment) interaction, showing significant differences for all traits (Table 1). To clarify the performance of the varieties along environments and estimate the stability of each variety for all traits, Fasoula [19] method along with AMMI and GGE analysis were performed. For almost all traits studied, the interaction between cultivation system, variety, and environments was very significant (except for dry matter). This finding means that we have to suggest certain varieties for certain environments and cultivation systems. GxE interaction (Table 1 (m.s.533.910** for fresh forage yield)) and Cultivation $\times$ environment interaction were very intense for all traits. Especially for fresh forage yield Cultivation $x$ variety mean square was found also very significant (Table 1 (m.s.: $\left.115.869^{* *}\right)$ ).

Stability estimations based on the stability index are presented in Tables 2-4. In Table 2, calculations across environments are included for all traits measured. Fresh forage yield stability exhibited values over 100 and especially in two environments over 200. Low values $(<100)$ were found for forage dry matter crude protein content $(\%)$ and ash content (\%) of dry matter and in some cases for a number of stems per plant. Days to 50\% of flowering showed extremely high values (>2000). The two farming systems presented slight differences, not significantly affecting stability estimations, but in some cases, stability indices were higher in low-input experiments. 


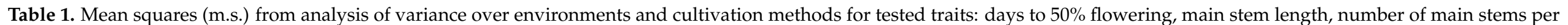
plant, fresh forage yield $\left(\mathrm{kg} \mathrm{ha}^{-1}\right)$, dry matter yield $\left(\mathrm{kg} \mathrm{ha}^{-1}\right)$, forage dry matter crude protein content $(\%)$ and ash content $(\%)$ of dry matter.

\begin{tabular}{|c|c|c|c|c|c|c|c|}
\hline Source of Variation & $\begin{array}{c}\text { Days to } 50 \% \\
\text { Flowering } \\
\text { m.s. }\end{array}$ & $\begin{array}{c}\text { Main Stem Length } \\
\text { m.s. }\end{array}$ & $\begin{array}{c}\text { Number of Stems per } \\
\text { Plant } \\
\text { m.s. }\end{array}$ & $\begin{array}{c}\text { Fresh Forage Yield } \\
\left(\mathrm{kg} \mathrm{ha}^{-1}\right) \\
\text { m.s. }\end{array}$ & $\begin{array}{c}\text { Dry Matter Yield } \\
\left(\mathrm{kg} \mathrm{ha}^{-1}\right) \\
\text { m.s. }\end{array}$ & $\begin{array}{c}\text { Forage Dry Matter } \\
\text { Crude Protein Content } \\
\qquad \begin{array}{c}(\%) \\
\text { m.s. }\end{array}\end{array}$ & $\begin{array}{c}\text { Ash Content (\%) of } \\
\text { Dry Matter } \\
\text { m.s. }\end{array}$ \\
\hline Environments (E) & $114.6^{* *}$ & $76.67^{\text {*** }}$ & $0.283 * *$ & $3353.77 * *$ & 306.9 ** & 7.523 ** & $0.438^{* *}$ \\
\hline REPS/Environments & $63.05^{* *}$ & $124.5^{\text {** }}$ & $0.972 * *$ & $1290.47^{* *}$ & $36.67^{* *}$ & $51.79 * *$ & $8.001^{* *}$ \\
\hline Varieties (G) & $152.2 * *$ & $8.066^{* *}$ & $1.357^{* *}$ & $1427.05^{* *}$ & $39.46^{* *}$ & $7.714^{* *}$ & $0.391 * *$ \\
\hline Environments $\times$ Varieties $(G \times E)$ & $7.744^{* *}$ & $11.11^{* *}$ & $0.239 * *$ & $533.910 * *$ & $43.20 * *$ & $3.590 * *$ & $0.201 * *$ \\
\hline Cultivations & $1.446^{*}$ & 18.24 ** & $0.090 *$ & $5618.32 * *$ & $648.5^{* *}$ & $10.07^{* *}$ & $0.120 \mathrm{~ns}$ \\
\hline Cultivation $\times$ Environments & $28.66^{* *}$ & $65.49^{* *}$ & $0.173^{* *}$ & $47.1549 * *$ & $36.89^{* *}$ & $2.190 * *$ & $0.187^{*}$ \\
\hline Cultivation $\times$ Varieties & 3.256 ** & $4.137^{* *}$ & $0.202 * *$ & $115.869 * *$ & $3.491 \mathrm{~ns}$ & $1.313 * *$ & $0.395 * *$ \\
\hline Error & 0.470 & $0.619^{* *}$ & 0.009 & 2.16051 & 7.942 & 0.249 & 0.087 \\
\hline
\end{tabular}

Probability values: $* x \leq 0.05 ;{ }^{* *} p \leq 0.01 ; \mathrm{ns}=$ not significant.

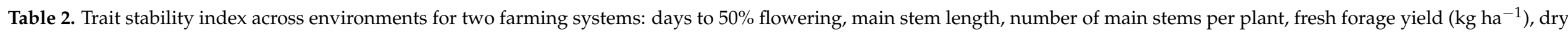
matter yield $\left(\mathrm{kg} \mathrm{ha}^{-1}\right)$, forage dry matter crude protein content $(\%)$ and ash content $(\%)$ of dry matter.

\begin{tabular}{|c|c|c|c|c|c|c|c|c|}
\hline & Environments & $\begin{array}{l}\text { Days to } 50 \% \\
\text { Flowering }\end{array}$ & $\begin{array}{l}\text { Main Stem } \\
\text { Length }\end{array}$ & $\begin{array}{c}\text { Number of Stems } \\
\text { per Plant }\end{array}$ & $\begin{array}{l}\text { Fresh Forage } \\
\left.\text { Yield (kg ha }{ }^{-1}\right)\end{array}$ & $\begin{array}{l}\text { Dry Matter Yield } \\
\quad\left(\mathrm{kg} \mathrm{ha}^{-1}\right)\end{array}$ & $\begin{array}{c}\text { Forage Dry } \\
\text { Matter Crude } \\
\text { Protein Content } \\
(\%)\end{array}$ & $\begin{array}{c}\text { Ash Content (\%) } \\
\text { of Dry Matter }\end{array}$ \\
\hline \multirow{3}{*}{ Conventional } & Florina & 5316 & 318 & 50 & 204 & 232 & 98 & 129 \\
\hline & Trikala & 2274 & 263 & 117 & 173 & 146 & 94 & 83 \\
\hline & Kalambaka & 3724 & 312 & 80 & 112 & 210 & 126 & 97 \\
\hline \multirow{3}{*}{ Low-inputs } & Giannitsa & 2922 & 319 & 108 & 243 & 126 & 104 & 109 \\
\hline & Trikala & 3062 & 360 & 117 & 192 & 251 & 109 & 99 \\
\hline & Kalambaka & 4920 & 271 & 192 & 139 & 259 & 130 & 78 \\
\hline \multirow{4}{*}{$\begin{array}{l}\text { Conventional\&Low- } \\
\text { inputs }\end{array}$} & Giannitsa & 2990 & 260 & 102 & 203 & 123 & 96 & 98 \\
\hline & Florina & 3882 & 223 & 58 & 197 & 256 & 98 & 110 \\
\hline & Trikala & 2629 & 258 & 118 & 166 & 139 & 102 & 91 \\
\hline & Kalambaka & 3930 & 292 & 113 & 120 & 231 & 125 & 87 \\
\hline
\end{tabular}




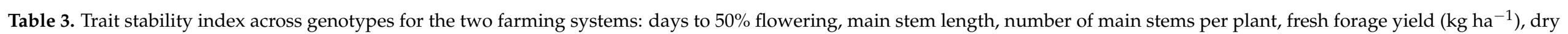
matter yield $\left(\mathrm{kg} \mathrm{ha}^{-1}\right)$, forage dry matter crude protein content $(\%)$ and ash content $(\%)$ of dry matter.

\begin{tabular}{|c|c|c|c|c|c|c|c|c|}
\hline & Genotypes & $\begin{array}{c}\text { Days to } 50 \% \\
\text { Flowering }\end{array}$ & $\begin{array}{l}\text { Main Stem } \\
\text { Length }\end{array}$ & $\begin{array}{c}\text { Number of Stems } \\
\text { per Plant }\end{array}$ & $\begin{array}{l}\text { Fresh Forage } \\
\text { Yield }\left(\mathrm{kg} \mathrm{ha}^{-1}\right)\end{array}$ & $\begin{array}{l}\text { Dry Matter Yield } \\
\quad\left(\mathrm{kg} \mathrm{ha}^{-1}\right)\end{array}$ & $\begin{array}{c}\text { Forage Dry } \\
\text { Matter Crude } \\
\text { Protein Content } \\
(\%)\end{array}$ & $\begin{array}{c}\text { Ash Content }(\%) \\
\text { of Dry Matter }\end{array}$ \\
\hline \multirow{4}{*}{ Conventional } & Omiros & 3944 & 254 & 150 & 122 & 95 & 122 & 122 \\
\hline & Alexandros & 3738 & 265 & 130 & 189 & 163 & 95 & 89 \\
\hline & Tempi & 4579 & 299 & 89 & 164 & 171 & 85 & 89 \\
\hline & Zefyros & 3124 & 261 & 68 & 196 & 176 & 93 & 79 \\
\hline \multirow{6}{*}{ Low-inputs } & Filippos & 2559 & 372 & 106 & 166 & 224 & 119 & 117 \\
\hline & Omiros & 3264 & 241 & 122 & 167 & 181 & 115 & 115 \\
\hline & Alexandros & 4586 & 198 & 130 & 163 & 201 & 112 & 93 \\
\hline & Tempi & 3584 & 260 & 141 & 180 & 151 & 110 & 87 \\
\hline & Zefyros & 2553 & 219 & 84 & 225 & 370 & 89 & 78 \\
\hline & Pigasos & 3321 & 256 & 85 & 250 & 249 & 101 & 80 \\
\hline \multirow{4}{*}{$\begin{array}{l}\text { Conventional\&Low- } \\
\text { inputs }\end{array}$} & Filippos & 3081 & 251 & 94 & 142 & 175 & 111 & 124 \\
\hline & Omiros & 3613 & 249 & 136 & 137 & 119 & 121 & 120 \\
\hline & Zefyros & 2813 & 242 & 73 & 207 & 217 & 92 & 78 \\
\hline & Pigasos & 3423 & 226 & 96 & 226 & 200 & 106 & 86 \\
\hline
\end{tabular}




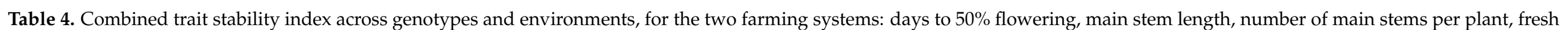
forage yield $\left(\mathrm{kg} \mathrm{ha}^{-1}\right)$, dry matter yield $\left(\mathrm{kg} \mathrm{ha}^{-1}\right)$, forage dry matter crude protein content $(\%)$ and ash content $(\%)$ of dry matter.

\begin{tabular}{|c|c|c|c|c|c|c|c|c|}
\hline & Genotypes & $\begin{array}{l}\text { Days to } 50 \% \\
\text { Flowering }\end{array}$ & Main Stem Length & $\begin{array}{c}\text { Number of Stems } \\
\text { per Plant }\end{array}$ & $\begin{array}{c}\text { Fresh Forage Yield } \\
\left(\mathrm{kg} \mathrm{ha}^{-1}\right)\end{array}$ & $\begin{array}{l}\text { Dry Matter Yield } \\
\left(\mathrm{kg} \mathrm{ha}^{-1}\right)\end{array}$ & $\begin{array}{c}\text { Forage Dry Matter Crude } \\
\text { Protein Content }(\%)\end{array}$ & $\begin{array}{c}\text { Ash Content (\%) o } \\
\text { Dry Matter }\end{array}$ \\
\hline & \multicolumn{8}{|c|}{ Giannitsa } \\
\hline \multirow{6}{*}{ Conventional } & Filippos & 4895 & 207 & 164 & 227 & 321 & 105 & 79 \\
\hline & Omiros & 4954 & 238 & 176 & 332 & 85 & 121 & 188 \\
\hline & Alexandros & 3138 & 194 & 147 & 211 & 125 & 81 & 99 \\
\hline & Tempi & 3306 & 212 & 134 & 409 & 59 & 97 & 58 \\
\hline & Zefyros & 5845 & 182 & 88 & 293 & 1063 & 71 & 76 \\
\hline & Pigasos & 3838 & 197 & 87 & 194 & 210 & 109 & 62 \\
\hline \multirow{5}{*}{ Low-inputs } & Filippos & 2906 & 374 & 113 & 295 & 275 & 161 & 140 \\
\hline & Alexandros & 4933 & 287 & 279 & 276 & 113 & 72 & 72 \\
\hline & Tempi & 2942 & 232 & 116 & 342 & 58 & 106 & 87 \\
\hline & Zefyros & 2750 & 313 & 71 & 373 & 1097 & 65 & 130 \\
\hline & Pigasos & 3155 & 337 & 158 & 271 & 207 & 71 & 117 \\
\hline \multirow{6}{*}{$\begin{array}{l}\text { Conventional\&Low- } \\
\text { inputs }\end{array}$} & Filippos & 3447 & 285 & 121 & 219 & 248 & 136 & 101 \\
\hline & Omiros & 3499 & 269 & 138 & 254 & 90 & 167 & 125 \\
\hline & Alexandros & 4042 & 232 & 154 & 234 & 115 & 72 & 89 \\
\hline & Tempi & 3108 & 235 & 133 & 324 & 62 & 108 & 74 \\
\hline & Zefyros & 3654 & 247 & 64 & 332 & 772 & 69 & 100 \\
\hline & Pigasos & 3387 & 239 & 107 & 212 & 208 & 92 & 86 \\
\hline \multirow{6}{*}{ Conventional } & Filippos & 19875 & 501 & 57 & 310 & 221 & 119 & 297 \\
\hline & Omiros & 5615 & 429 & 150 & 355 & 245 & 101 & 148 \\
\hline & Alexandros & 19639 & 287 & 292 & 286 & 294 & 74 & 121 \\
\hline & Tempi & 5401 & 343 & 40 & 144 & 859 & 88 & 115 \\
\hline & Zefyros & 5985 & 216 & 63 & 369 & 172 & 207 & 113 \\
\hline & Pigasos & 4718 & 315 & 62 & 232 & 379 & 98 & 111 \\
\hline \multirow{6}{*}{ Low-inputs } & Filippos & 3011 & 416 & 78 & 313 & 510 & 85 & 121 \\
\hline & Omiros & 4523 & 226 & 106 & 494 & 284 & 81 & 118 \\
\hline & Alexandros & 3232 & 115 & 213 & 247 & 490 & 116 & 92 \\
\hline & Tempi & 2976 & 197 & 91 & 414 & 329 & 83 & 55 \\
\hline & Zefyros & 3768 & 154 & 54 & 228 & 746 & 81 & 70 \\
\hline & Pigasos & 3637 & 141 & 43 & 145 & 157 & 120 & 140 \\
\hline \multirow{6}{*}{$\begin{array}{l}\text { Conventional\&Low- } \\
\text { inputs }\end{array}$} & Filippos & 5604 & 480 & 70 & 330 & 314 & 104 & 181 \\
\hline & Omiros & 5332 & 298 & 132 & 384 & 274 & 96 & 140 \\
\hline & Alexandros & 5094 & 163 & 225 & 284 & 223 & 96 & 112 \\
\hline & Tempi & 3909 & 263 & 60 & 143 & 457 & 86 & 79 \\
\hline & Zefyros & 4955 & 182 & 58 & 302 & 287 & 124 & 86 \\
\hline & Pigasos & 4389 & 209 & 54 & 179 & 236 & 112 & 129 \\
\hline
\end{tabular}


Table 4. Cont.

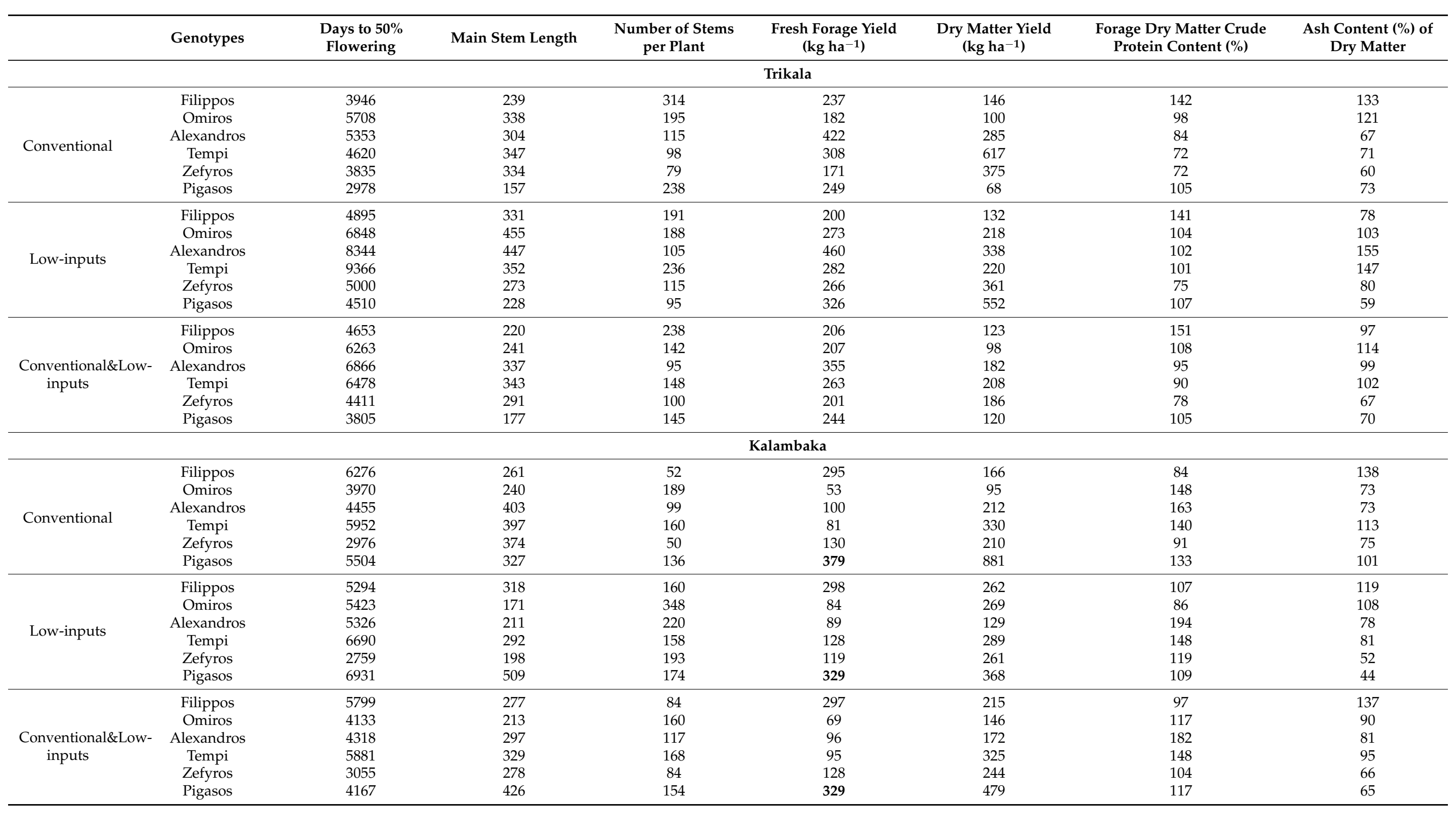


Table 3 depicts the differences between the six varieties. (Alexandros) and (Tempi) showed the highest values for days to $50 \%$ of flowering (>4000), while (Pigasos) and (Zefyros) for fresh forage yield (>200) across environments. Combined estimations, also displayed stability for fresh forage yield of (Pigasos) and (Zefyros). Comparisons between the conventional and low-input farming systems generally showed minor differences but revealed varieties that exhibit stable performance even in low-input farming systems where stability is generally a little higher. This is a very important finding for the introduction of productive varieties in low-input farming systems.

In Table 4 stability indices combine both environmental and genotypic behavior for all traits studied, for the two cultivation systems (conventional and low-inputs). Trikala and Florina showed some extreme stability index values for the number of days to $50 \%$ of flowering, indicating a perfect environment for estimating flowering and total development period, due to the contribution of the certain environment. According to Table 4, a combination of variety-environment may exhibit a favored performance for some traits, which exhibit considerable stability. For example, for a number of days to $50 \%$ of flowering, (Zefyros), (Filippos) and (Omiros) showed the highest values in conventional farming systems, while Alexandros in low-inputs, and for the environmental area of (Giannitsa). For (Trikala) and (Florina) favored the same trait in an extreme way, especially for (Alexandros). For dry matter, (Zefyros) was favored for stability in both cultivation systems in (Giannitsa).

The AMMI1 and GxE biplot analysis were used to visualize the data presented in Tables 2 and 4 . The AMMI1 and $\mathrm{G} \times \mathrm{E}$ biplot analysis on the main factor (that we may call adaptability in environments), showed different grouping of varieties and, concerning fresh forage yields, (Zefyros) outyielded all other varieties (Figure 2). Genotype and environment distribution were used to group varieties which better perform in certain environments (Figure 3). In Figures 4 and 5, it can be clearly seen that (Zefyros) is in the optimal position. For forage dry matter productivity G6 (Omiros) was the most stable variety, followed by G5 (Zefyros). The AMMI1 and GGE biplots analysis gave the same results. Regarding the crude protein content, the desirable varieties were the G2 (Omiros) and G6 (Pigasos). As for the days to $50 \%$ flowering both AMMI1 and GGE biplots analysis resulted that the varieties (G1 (Filippos), G2 (Omiros), G3 (Alexandros), G4 (Tempi), G6 (Pigasos)) formed one group which was characterized by relative stability (Figure 6). The G5 (Zefyros) was placed on the opposite side of the vector alone and near the ideal genotype and the average environment. $\mathrm{G} \times \mathrm{E}$ biplot may explore both environment and genotype behavior concerning yield traits stability performance over environments and years. Regarding the ash content no variety placed near the ideal one (Figure 7). 


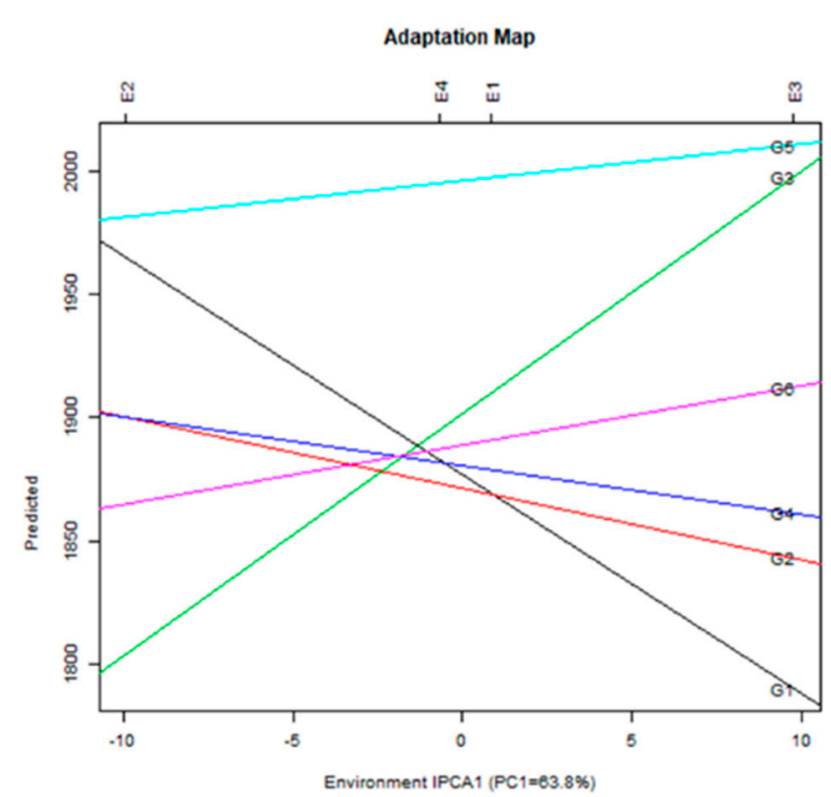

(a)

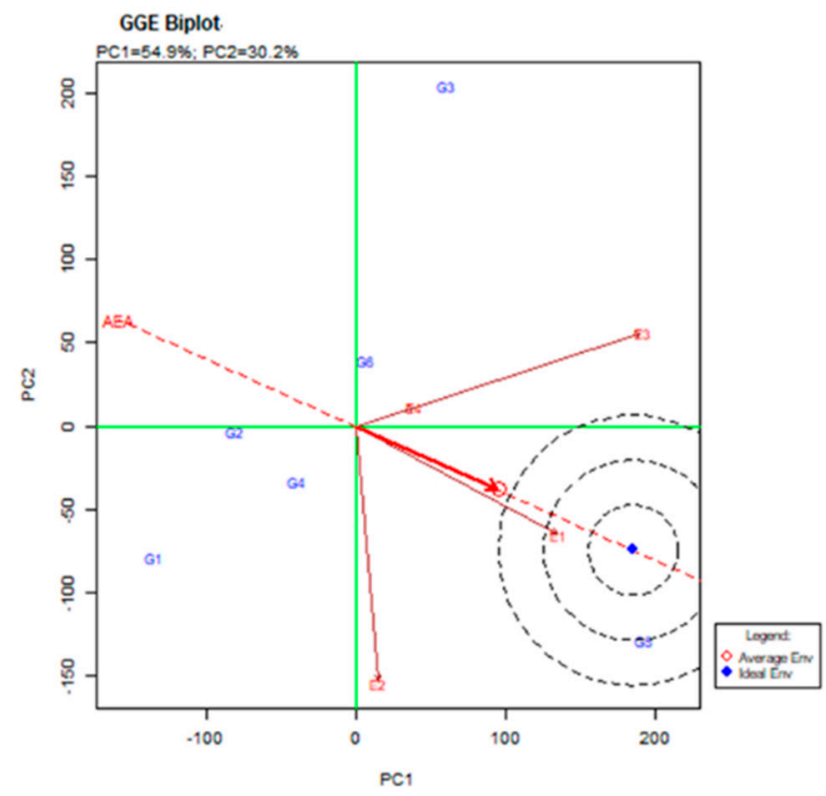

(c)

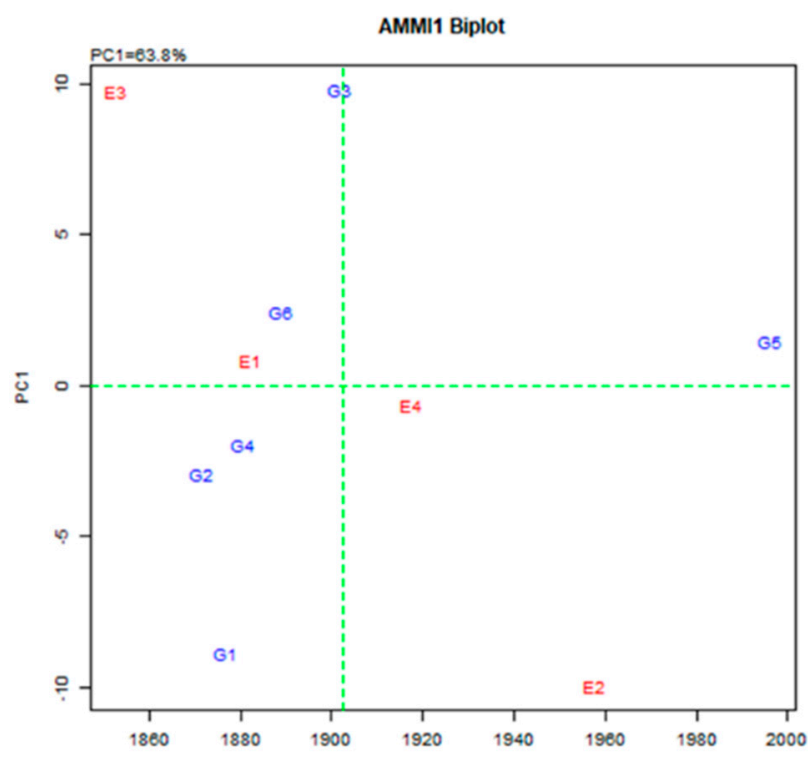

(b)

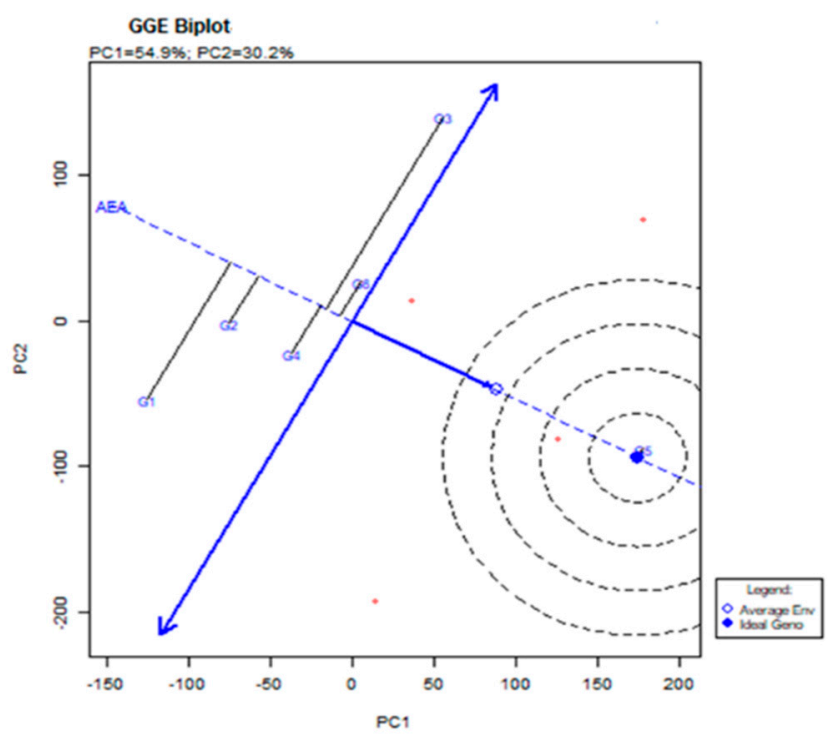

(d)

Figure 2. Stability analysis for fresh forage yield $\left(\mathrm{kg} \mathrm{ha}^{-1}\right)$ based on (a) the adaptation map where the X-axis (PC1) visualizes the stability of varieties over environments and the Y-axis-the performance of varieties for the trait; (b) the AMMI1 biplot where the Y-axis is the one visualizing the trait performance and the X-axis (PC1) visualizes the stability of varieties over environments; (c) the GGE biplot for environments depicting the stability of the environments over years via the placement as near as possible to the ideal and average environment; (d) the GGE biplot for varieties depicting the stability of the varieties over environments where the productive varieties are those to the right on the AEA vector and the stable ones are those which are as close to the AEA axis as possible. 


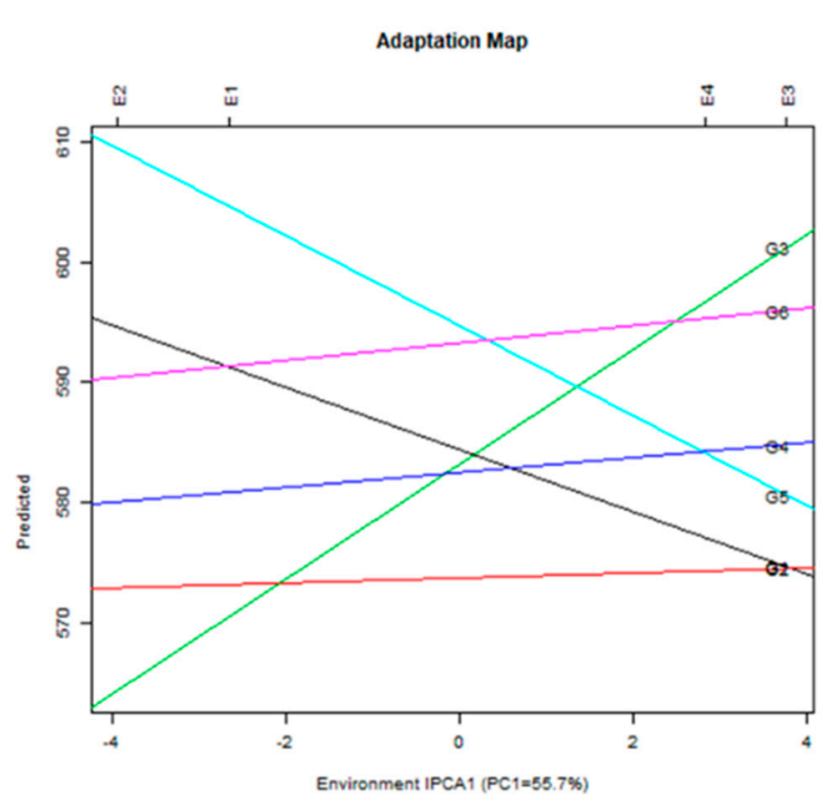

(a)

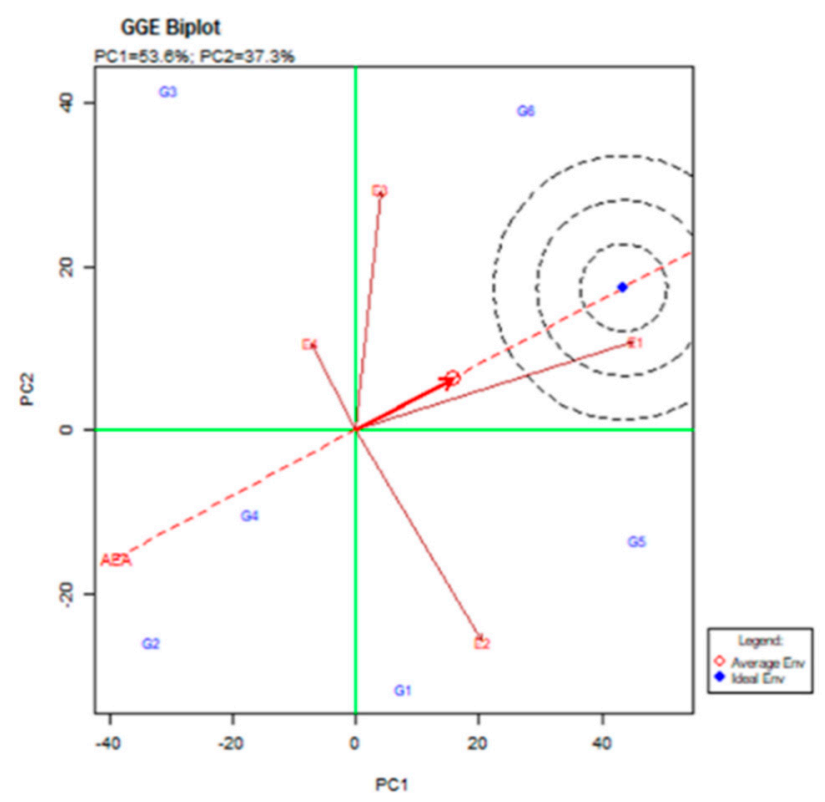

(c)

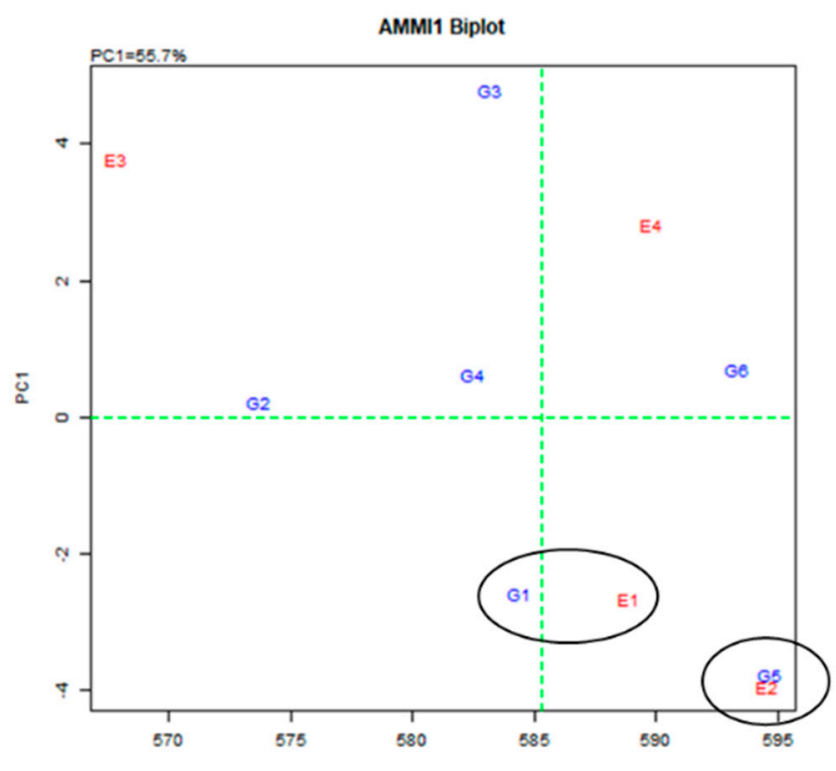

(b)

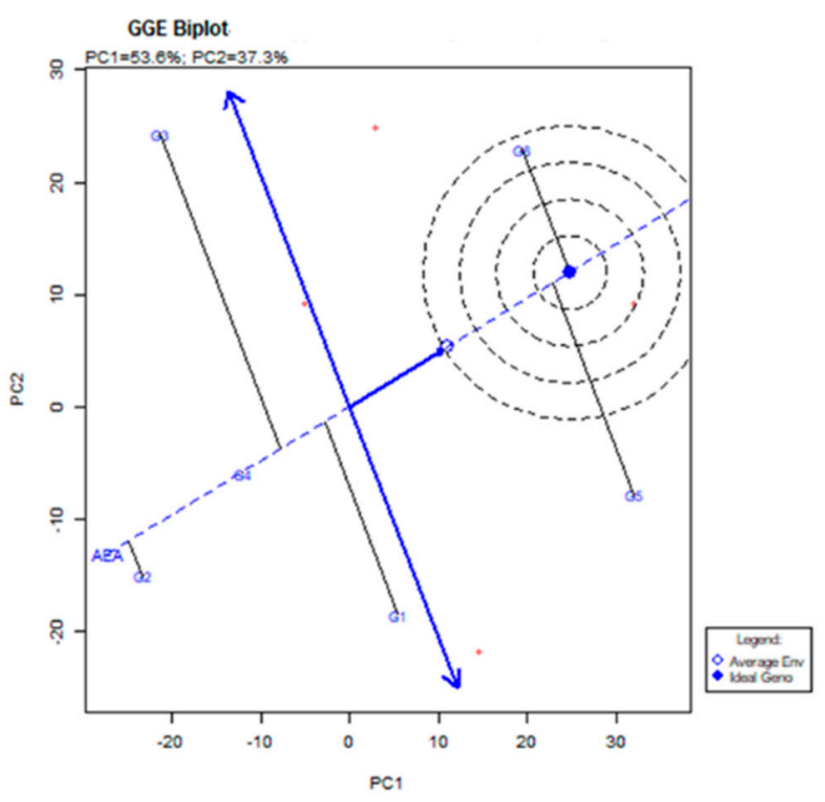

(d)

Figure 3. Stability analysis for forage dry matter yield $\left(\mathrm{kg} \mathrm{ha}^{-1}\right)$ based on: (a) the adaptation map where the X-axis (PC1) visualizes the stability of varieties over environments and the Y-axis—the performance of varieties for the trait; (b) the AMMI1 biplot where the Y-axis is the one visualizing the trait performance and the X-axis (PC1) visualizes the stability of varieties over environments; (c) the GGE biplot for environments depicting the stability of the environments over years via the placement as near as possible to the ideal and average environment; (d) the GGE biplot for varieties depicting the stability of the varieties over environments where the productive varieties are those to the right on the AEA vector and the stable ones are those which are as close to the AEA axis as possible. 


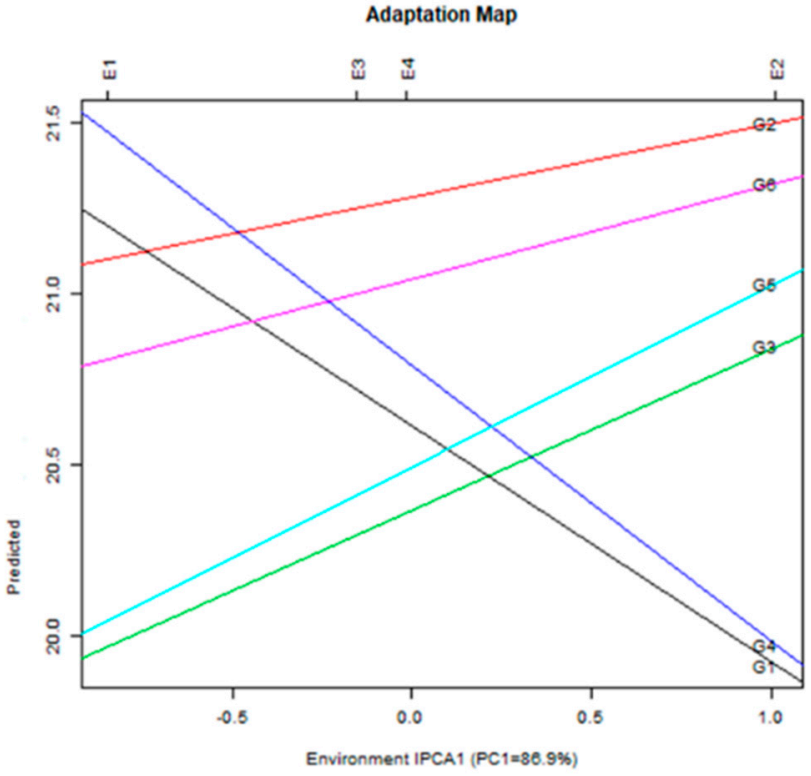

(a)

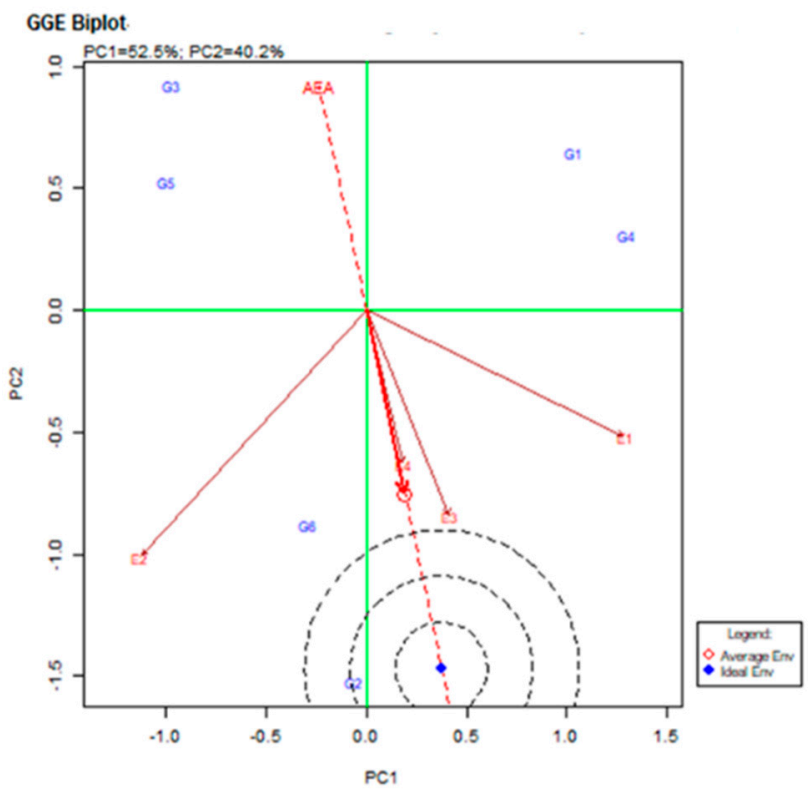

(c)

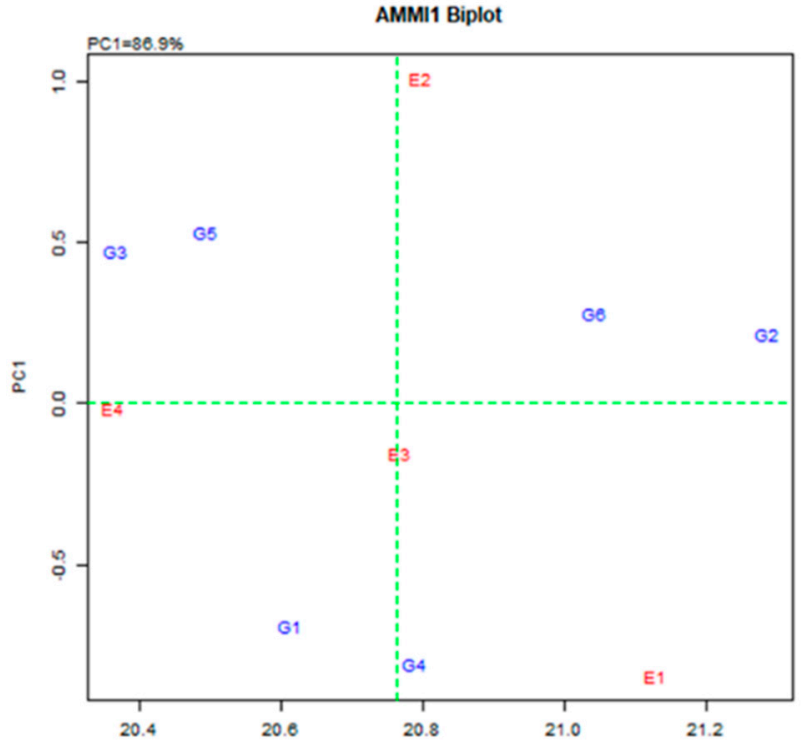

(b)

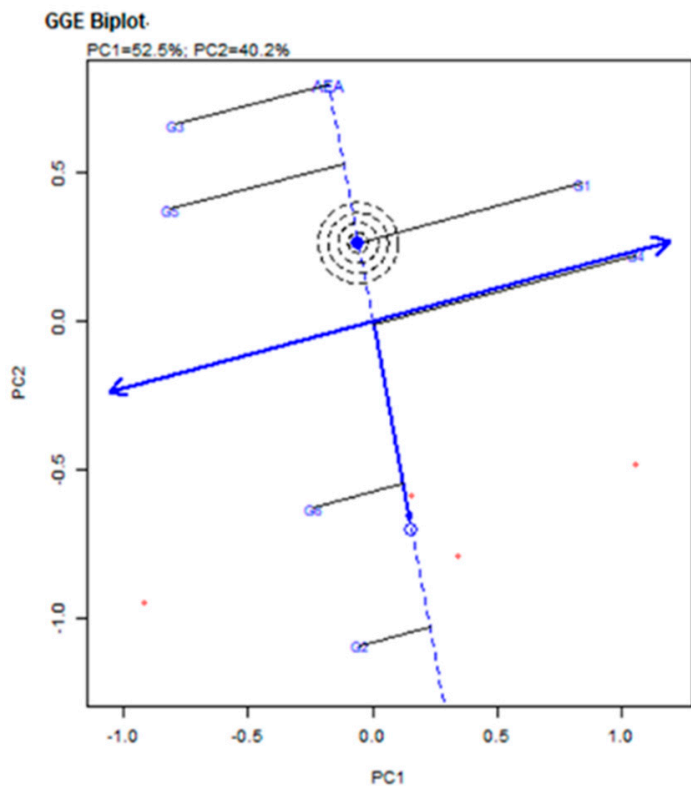

(d)

Figure 4. Stability analysis for crude protein content (\%) based on: (a) the adaptation map where the X-axis (PC1) visualizes the stability of varieties over environments and the Y-axis—-the performance of varieties for the trait; (b) the AMMI1 biplot where the $\mathrm{Y}$-axis is the one visualizing the trait performance and the X-axis (PC1) visualizes the stability of varieties over environments; (c) the GGE biplot for environments depicting the stability of the environments over years via the placement as near as possible to the ideal and average environment; (d) the GGE biplot for varieties depicting the stability of the varieties over environments where the productive varieties are those to the right on the AEA vector and the stable ones are those which are as close to the AEA axis as possible. 


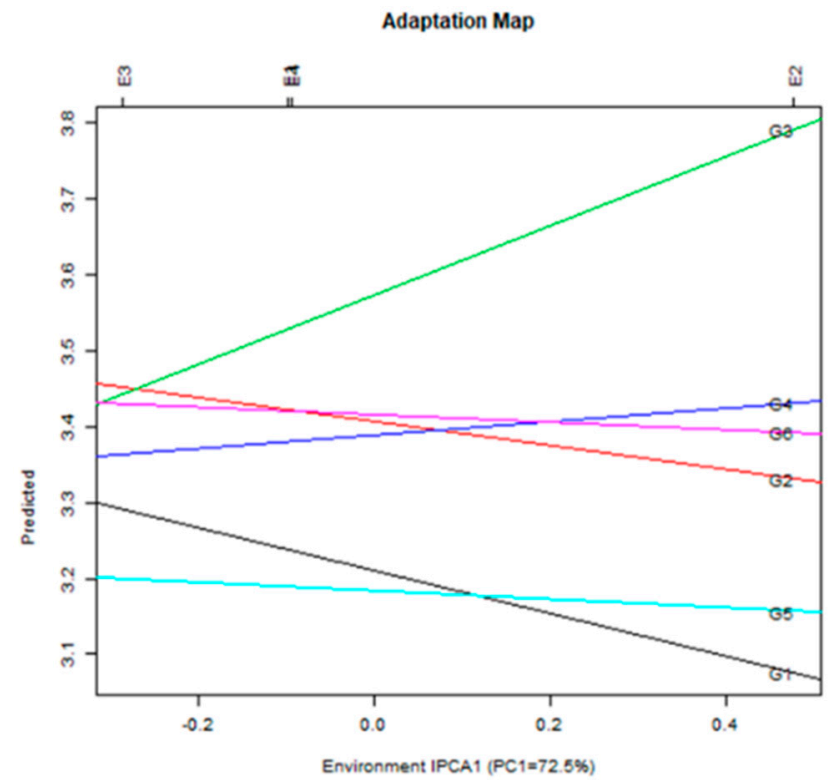

(a)

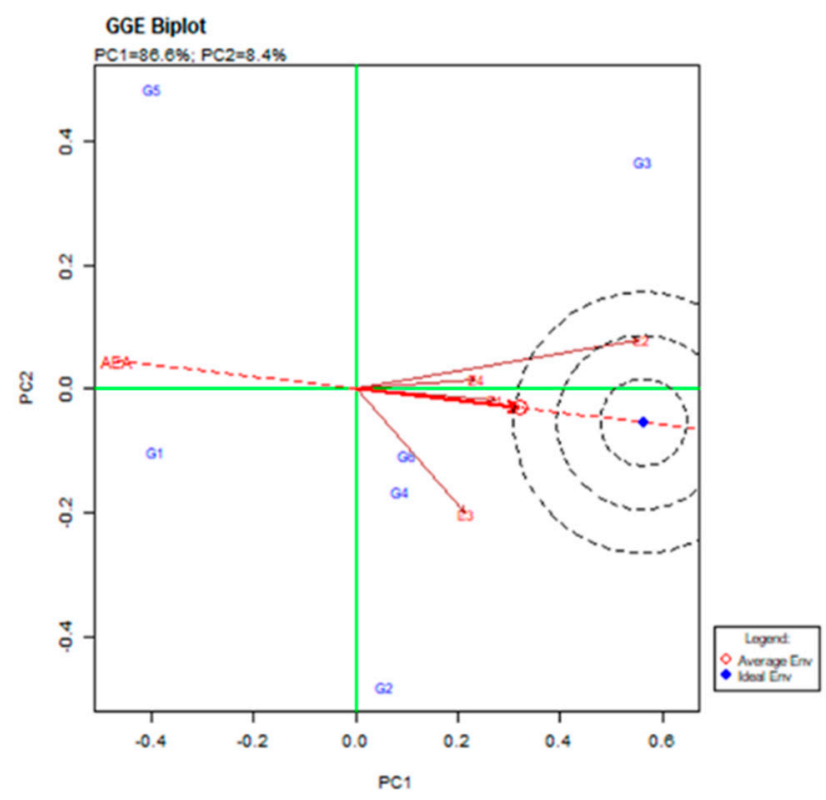

(c)

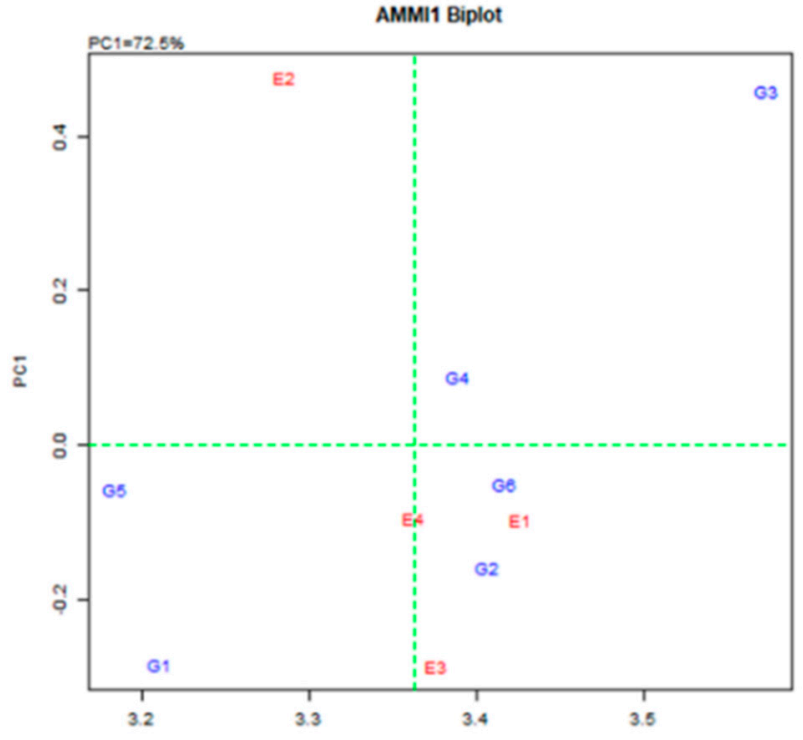

(b)

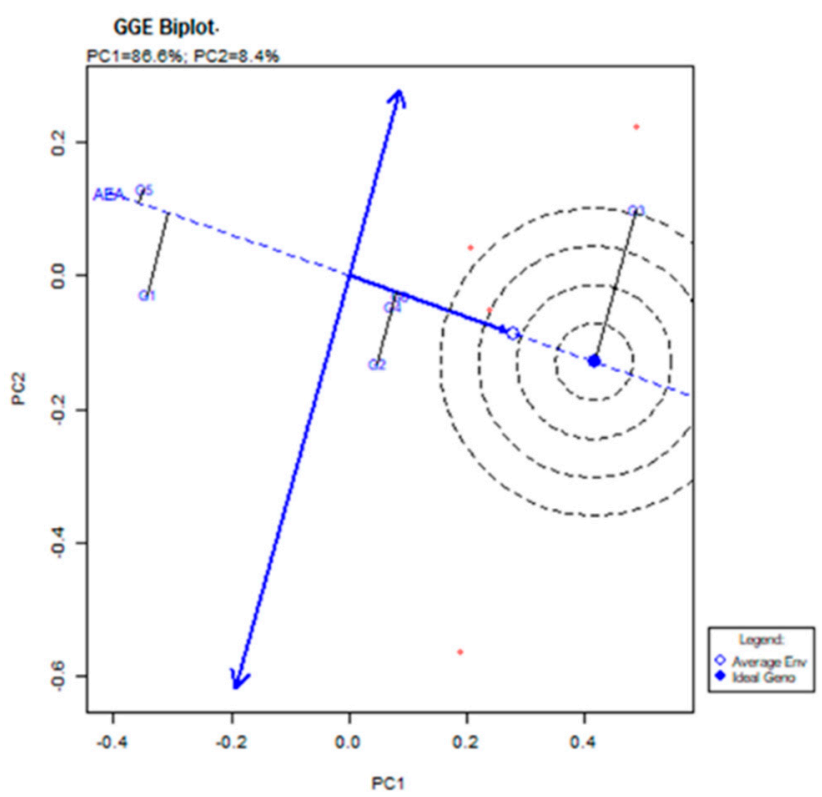

(d)

Figure 5. Stability analysis for the number of stems per plant based on: (a) the adaptation map where the X-axis (PC1) visualizes the stability of varieties over environments and the Y-axis-the performance of varieties for the trait; (b) the AMMI1 biplot where the Y-axis is the one visualizing the trait performance and the X-axis (PC1) visualizes the stability of varieties over environments; (c) the GGE biplot for environments depicting the stability of the environments over years via the placement as near as possible to the ideal and average environment; (d) the GGE biplot for varieties depicting the stability of the varieties over environments where the productive varieties are those to the right on the AEA vector and the stable ones are those which are as close to the AEA axis as possible. 


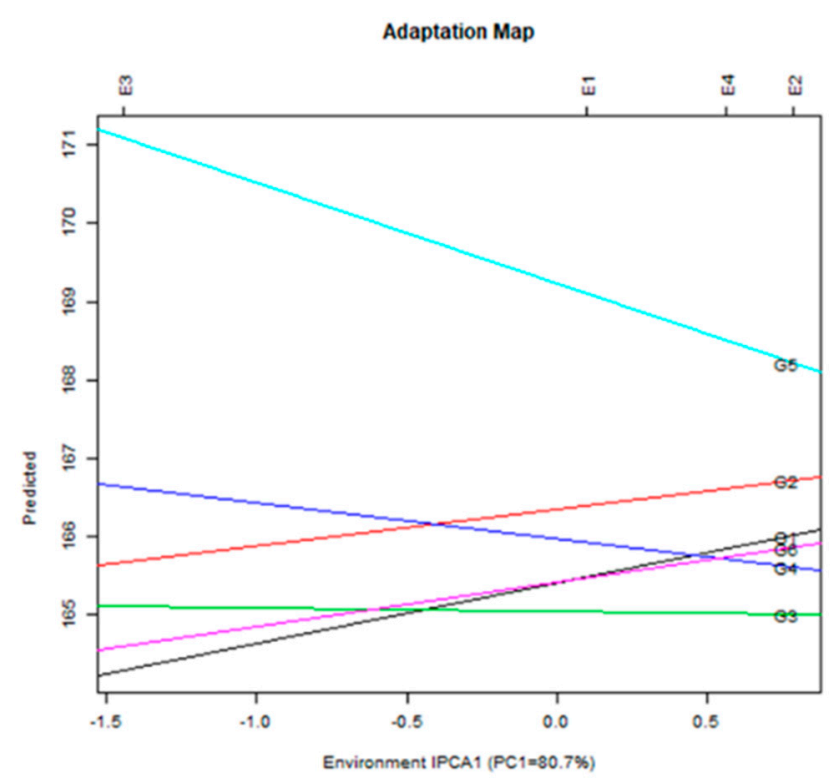

(a)

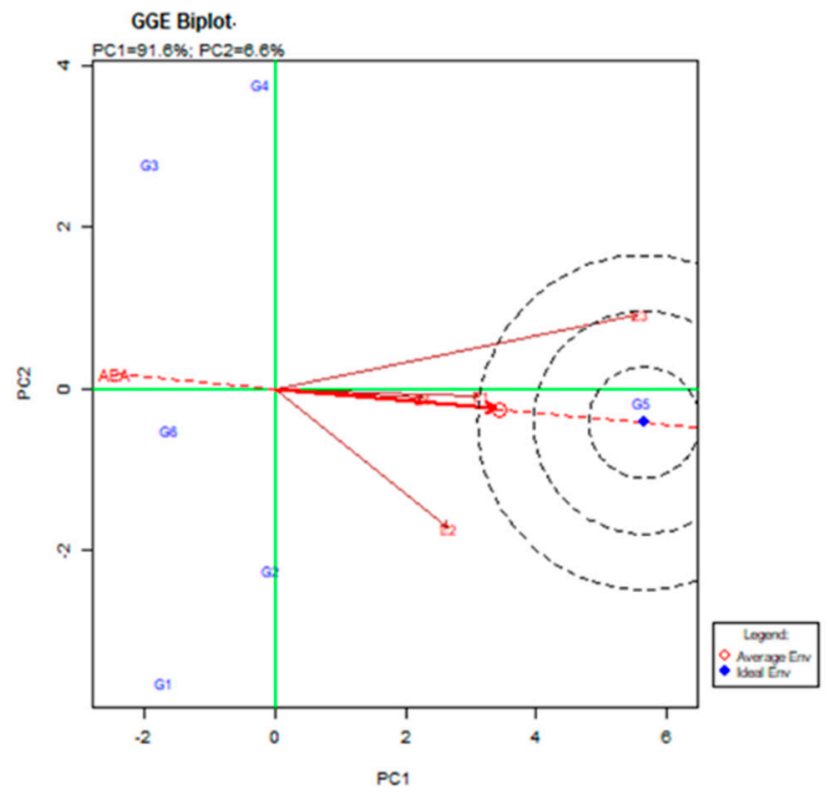

(c)

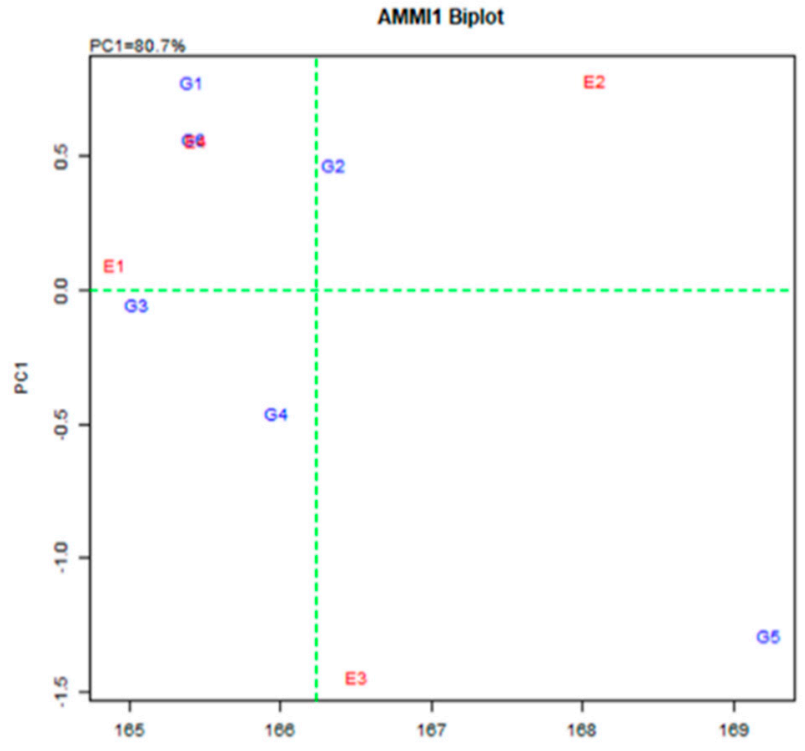

(b)

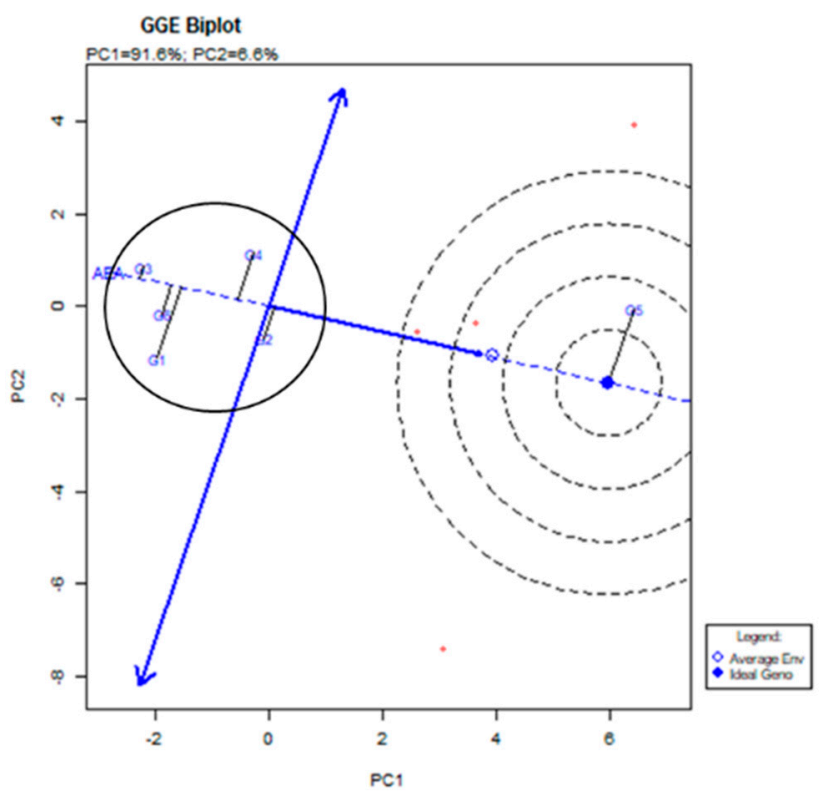

(d)

Figure 6. Stability analysis for days to $50 \%$ flowering based on: (a) the adaptation map where the X-axis (PC1) visualizes the stability of varieties over environments and the Y-axis—-the performance of varieties for the trait; (b) the AMMI1 biplot where the $\mathrm{Y}$-axis is the one visualizing the trait performance and the X-axis (PC1) visualizes the stability of varieties over environments; (c) the GGE biplot for environments depicting the stability of the environments over years via the placement as near as possible to the ideal and average environment; (d) the GGE biplot for varieties depicting the stability of the varieties over environments where the productive varieties are those to the right on the AEA vector and the stable ones are those which are as close to the AEA axis as possible. 


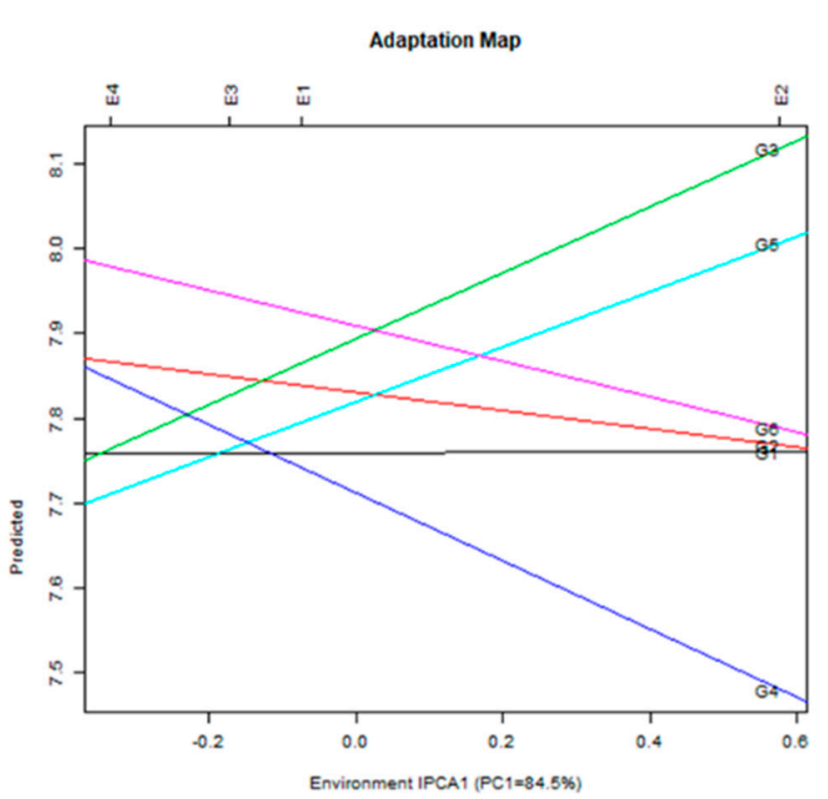

(a)

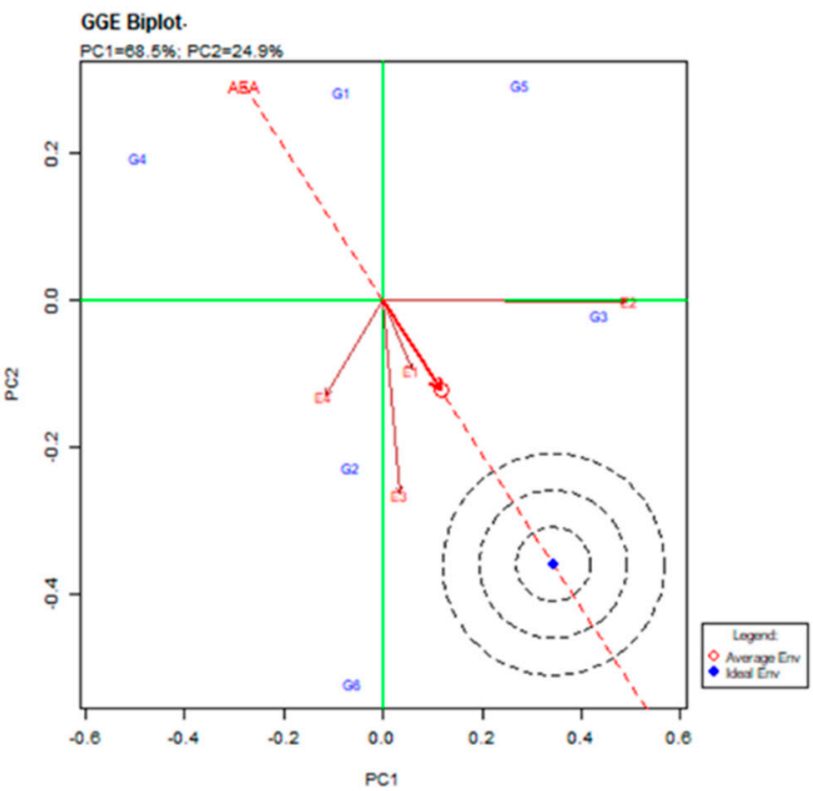

(c)

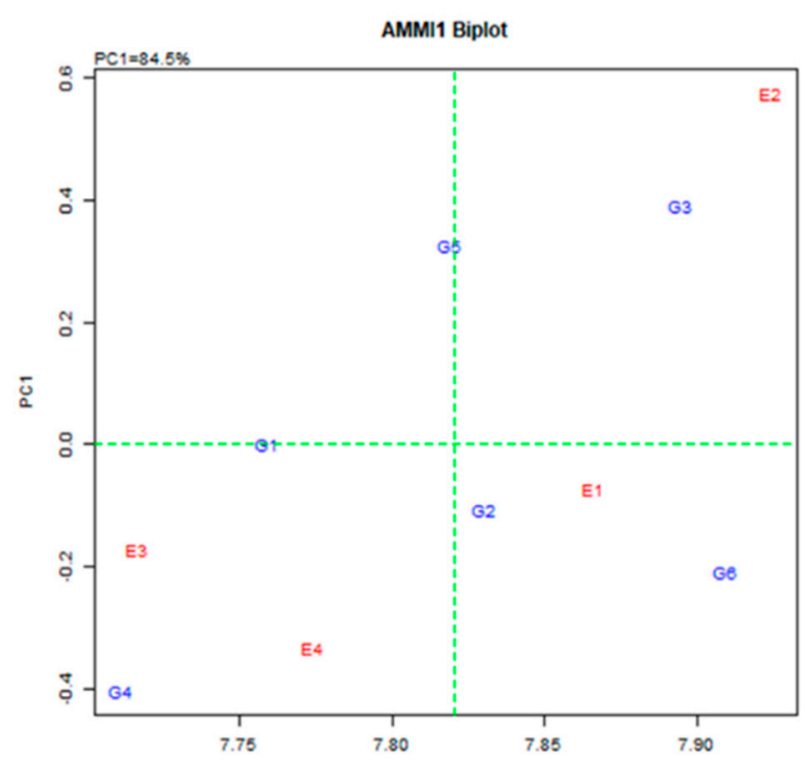

(b)

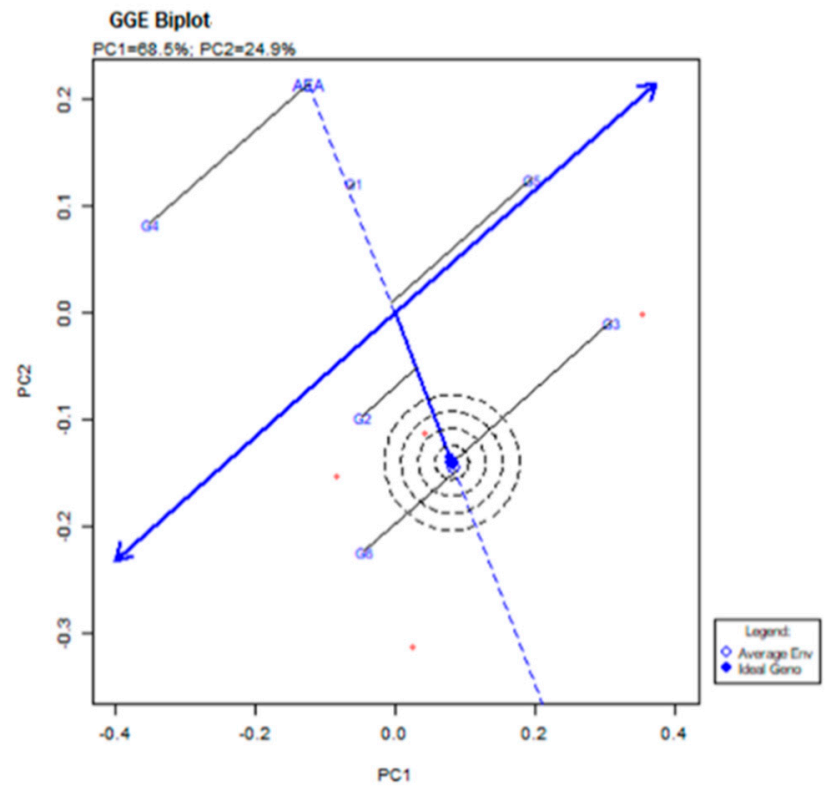

(d)

Figure 7. Stability analysis for ash content (\%) based on: (a) the adaptation map where the X-axis (PC1) visualizes the stability of varieties over environments and the Y-axis—the performance of varieties for the trait; (b) the AMMI1 biplot where the Y-axis is the one visualizing the trait performance and the X-axis (PC1) visualizes the stability of varieties over environments; (c) the GGE biplot for environments depicting the stability of the environments over years via the placement as near as possible to the ideal and average environment; (d) the GGE biplot for varieties depicting the stability of the varieties over environments where the productive varieties are those to the right on the AEA vector and the stable ones are those which are as close to the AEA axis as possible.

For AMMI analysis as visualized by the adaptation map figure, the most desirable varieties were those placed high on the axis of trait performance showing a nearly parallel line to the PC1 axis, which was an indication of stability over the environments.

For the AMMI1 biplot the desirable varieties were those placed high on the axis of trait performance (x-axis, right position) and close to the center of the PC1 axis (near zero). 
Regarding the GGE biplot for environments, the most stable environment was that placed close to the dot of ideal and average environment and in the concentric area of the ideal environment dot.

Concerning GGE biplot for varieties, the desirable varieties (stable and productive) were those placed to the ideal variety and in the concentric area of the ideal variety dot.

\section{Correlations between Characteristics}

Correlations between the traits (Table 5) displayed the positive relation of fresh forage yield with days for $50 \%$ flowering $(r=0.202)$ and dry forage yield $(r=0.501)$. A few more positive or negative correlations are also presented in Table 4.

Table 5. Correlations between all traits measured: days to $50 \%$ flowering, main stem length, a number of main stems per plant, fresh forage yield $\left(\mathrm{kg} \mathrm{ha}^{-1}\right)$, dry matter yield $\left(\mathrm{kg} \mathrm{ha}^{-1}\right)$, forage dry matter crude protein content $(\%)$, and ash content (\%) of dry matter.

\begin{tabular}{|c|c|c|c|c|c|c|}
\hline & $\begin{array}{l}\text { Days to } 50 \% \\
\text { Flowering }\end{array}$ & $\begin{array}{l}\text { Main Stem } \\
\text { Length }\end{array}$ & $\begin{array}{c}\text { Number of Stems } \\
\text { per Plant }\end{array}$ & $\begin{array}{l}\text { Fresh Forage } \\
\text { Yield (kg ha-1) }\end{array}$ & $\begin{array}{l}\text { Dry Matter Yield } \\
\left(\mathrm{kg} \mathrm{ha}^{-1}\right)\end{array}$ & $\begin{array}{c}\text { Forage Dry Matter } \\
\text { Crude Protein } \\
\text { Content }(\%)\end{array}$ \\
\hline Main stem length & 0.012 & & & & & \\
\hline Number of stems per plant & 0.083 & 0.038 & & & & \\
\hline Fresh forage yield $\left(\mathrm{kg} \mathrm{ha}^{-1}\right)$ & $0.202 * *$ & $0.119 *$ & $-0.134^{* *}$ & & & \\
\hline Dry matter yield $\left(\mathrm{kg} \mathrm{ha}^{-1}\right)$ & 0.085 & 0.070 & 0.016 & $0.501^{* *}$ & & \\
\hline $\begin{array}{l}\text { Forage dry matter crude } \\
\text { protein content }(\%)\end{array}$ & 0.036 & 0.037 & -0.024 & 0.062 & 0.041 & \\
\hline Ash Content (\%) of Dry matter & -0.021 & 0.041 & $0.142 * *$ & -0.064 & 0.004 & 0.006 \\
\hline
\end{tabular}

* Correlationis significant at the 0.05 level (2-tailed). ${ }^{* *}$ Correlation is significant at the 0.01 level (2-tailed).

\section{Discussion}

Breeders are developing varieties that must express high yield and stability of performance $[7,11]$, especially for forage yield that is useful for livestock support [26].

In our work, the two cultivation systems (conventional and low-input) displayed differences in variety performance, but in total, the different cultivation systems did not affect the stability performance of the traits tested. In combination with GGE biplot analysis, the two farming systems revealed the most stable varieties across all environments, as well as the more stable in specific environments. Additionally, some varieties exhibited stability in the low-input farming system and that is a common practice in many cultivation areas to support the increasing livestock's nutrition needs. Generally, there were GGE interactions that may limit variety selection for cultivation. Some environment combinations may form mega-environments, in the sense of the ones referred to in other works [25].

Combined estimations, also depicted stability for fresh forage yield of (Pigasos) and (Zefyros). The availability of proper varieties is very important to stabilize forage yield performance in low-input organic farming systems [9,27].

Using GGE biplot analysis, Aydemir et al. [28] concluded that various yield components like biological yield, straw yield, forage yield, and natural plant height, resulted in highly significant variations in common vetch cultivated in three different ecological locations that may be useful to breeders. The AMMI and GGE biplots is a very useful tool for breeders for selection of the proper genotypes to be cultivated in certain environments.

Sayar [29] evaluated genotype $\times$ environment interactions and stability of twenty common vetch (Vicia sativa L.) genotypes for fresh forage yield traits by using additive main effects and multiplicative interactions analysis (AMMI). Additive main effects and multiplicative interactions analysis (AMMI) showed that genotype $\times$ environment interactions were found very high for fresh forage yield traits. Some genotypes exhibited high and stable forage yield in certain environmental conditions. 


\subsection{Fresh Forage Yield}

The adaptation map and the AMMI1 analysis explained $63.8 \%$ of total variability for varieties' performance over all environments. Regarding the fresh forage yield and adaptation map Figure 2a the varieties tested, the G5 variety (Zefyros) was the most stable and productive over all varieties in all environments. The varieties G2 (Omiros), G4 (Tempi), and G6 (Pigasos) showed more or less an average productivity in all environments. The varieties G3 (Alexandros) and G1 (Filippos) showed environmental-specific adaptation whereas the G3 (Alexandros) favored by the E3 (Trikala) environment and the G1 (Filippos) from the E2 (Florina). The environments E3 (Trikala) and E2 (Florina) contributed to the variability for the fresh forage yield expressed by the varieties. Regarding the environments, the E1 (Giannitsa) and E4 (Kalambaka) seemed to be stable over the years of experimentation. The AMMI1 biplot analysis Figure $2 \mathrm{~b}$ showed that the most stable and productive variety was the G5 (Pigasos). The varieties G3 (Alexandros) and G1 (Filippos) seemed to be less stable compared to the other varieties, since they were placed, far away from the center and to the positive and negative edges of the PC1 axis. The varieties G6 (Pigasos), G4 (Tempi), and G2 (Omiros) showed medium to low productivity but expressed stability. The GGE biplot for either environments Figure 2c and Varieties Figure 2d explained 85.1\% (PC1: 54.9\%, PC2: $30.2 \%$ ) of the total variability. According to the GGE biplot for environments, there was one environment placed very close to the ideal one regarding the fresh forage productivity and it was the E1 (Giannitsa). Based on the GGE biplot analysis for the varieties tested, the G5 (Zefyros) variety was placed almost identical to the ideal variety. All other varieties appeared to be less stable, with lower productivity, as compared to the G5 (Zefyros) variety.

\subsection{Forage Dry Matter Yield}

Regarding the dry matter weight, the analysis via adaptation map and AMMI1 biplot explained $55.7 \%$ of the total variability. The adaptation map Figure 3a showed that the G6 (Pigasos) variety was the most stable and productive over all environments. The varieties G4 (Tempi) and G2 (Omiros) were stable but with less productivity. The varieties G3 (Alexandros), G5 (Zefyros), and G1 (Filippos) showed specific adaptation for high productivity. The G3 (Alexandros) was better adapted to the E3 (Trikala) environment whereas, in the E2 (Florina) environment, it was G5 (Zefyros) and G1 (Filippos). The AMMI1 biplot analysis Figure $3 \mathrm{~b}$ indicated that the most stable and productive variety was the G6 (Pigasos) and equally productive but showing specific adaptation in environment E2 (Florina) was the G5 (Zefyros). The G1 (Filippos) variety showed medium productivity and selective adaptation to the E1 (Giannitsa) environment. The GGE biplot analysis for environments and varieties Figure 3c, Figure 3d explained a high amount of variability reaching $90.9 \%$ (PC1: 53.6\%, PC2:37.3\%). Based on the environments GGE biplot, the average environment depicted away from the ideal and the E2 (Florina) was placed near the ideal environment. The GGE biplot for the genotypes showed that the G6 (Pigasos) variety and G5 (Zefyros) tended to be near the ideal variety.

\subsection{Crude Protein Content}

Regarding the crude protein content, both adaptation map and AMMI1 biplot analysis explained $86.9 \%$ of the total variability. According to adaptation map Figure $4 \mathrm{a}$, the most stable varieties for high protein production were the G2 (Omiros) and G6 (Pigasos), followed by the G5 (Zefyros) and G3 (Alexandros) which expressed lower protein content. The G4 (Tempi) and G1 (Filippos) showed specific adaptability and expressed very high protein content in E1 (Giannitsa) environment. AMMI1 biplot analysis Figure 4b showed that the G2 (Omiros) and G6 (Pigasos) varieties were the most productive and stable over all environments, followed by G3 (Alexandros) and G5 (Zefyros). The GGE biplot for environments showed that the average environment placed away from the ideal, and all environments appeared to be very diverse. The GGE biplot for varieties indicated that the most stable varieties were the G2 and G6, which were placed close to the average 
environment dot. No variety was placed near the ideal one, which was an indication for high variability existence for this trait.

\subsection{Number of Stems per Plant}

The adaptation map and AMMI1 biplots analysis explained $72.5 \%$ of the total variability. The results from the adaptation map in Figure 5a showed that the G3 variety was the one with the higher number of stems per plant and quite stable. All other varieties regarding this trait showed higher stability over environments with a lower number of stems. The AMMI1 biplots analysis, Figure 5b, indicated that the G3 (Alexandros) variety was placed higher on the PC1 axis, expressed low stability for the trait across environments, but with a high number of stems. All other varieties expressed better stability along with an average number of stems per plant. Across the varieties, the G5 (Zefyros) and G1 (Filippos) had the lowest number of stems per plant. The GGE biplot analysis, as depicted by Figure 5c,d, explained 95\% (PC1: 86.6\%, PC2: 8.4\%) of the total variability. In the area of the concentric circles around the ideal environment, only the E2 seemed to be placed near the ideal one Figure 4c. Regarding the varieties, the G3 (Alexandros) was placed near the ideal variety dot.

\subsection{Days to $50 \%$ Flowering}

For the days to $50 \%$ flowering, the figures of adaptation map and AMMI1 biplot analysis explained $80.7 \%$ of the total variability. The adaptation map showed that the G5 (Zefyros) variety needed more days for the 50\% flowering stage and seemed to be less stable than all the others. All other varieties showed that need more or less the same number of days for the 50\% flowering stage and expressed better stability from the G5 (Zefyros) variety. The same results occurred from the AMMI1 biplot analysis Figure 6b. The GGE biplot analysis for environments and varieties explained 98.2\% (PC1: 91.6\%, PC2:6.6\%) of the total variability. Across the environments, the most stable were those placed near the dots of ideal environment and average environment and were the E3 (Trikala) and E1 (Giannitsa). Based on the GGE biplot for varieties (Figure 6d), the varieties G1 (Filippos), G2 (Omiros), G3 (Alexandros), G4 (Tempi), and G6 (Pigasos) formed one group which was characterized by relative stability the variety G5 (Zefyros) was placed on the opposite side of the vector alone and near the ideal genotype and the average environment. The grouping of the varieties discriminates between early and late varieties, whereas G5 (Zefyros) was the late one.

\subsection{Ash Content}

The ash content as analyzed using the adaptation map and AMMI1 biplot figures explained $84.5 \%$ of total variability, Figure $7 \mathrm{a}, \mathrm{b}$. The varieties that showed specific adaptability for ash content where the G3 (Alexandros) and the G5 (Zefyros) varieties adapted better to E3 (Trikala) and E4 (Kalambaka) environments. The GGEbiplot analysis for environments and varieties explained 93.4\% (PC1: 68.8\%, PC2: 24.9\%) of total variability and showed that no environment placed near the ideal one Figure $7 \mathrm{c}$ and no variety near the ideal variety Figure 7d. All varieties expressed relatively low stability between the environments.

\subsection{Correlations between Characteristics}

In our study, correlations between traits displayed the positive relation of fresh forage yield with days for 50\% flowering and dry forage yield. Positive correlations may be proved useful for indirect breeding and selection of traits that show low stability through more stable ones. This is in accordance with Tiryaki et al. [30] findings and very useful to breeders. Correlations, in the same sense, were also reported for other traits in common vetch by Greveniotis et al. [31]. As Sayar [32] depicted, correlation coefficient analysis showed that yield component traits with the greatest effects on fresh forage yield were dry matter yield and main stem height, in common vetch varieties and correlations were very significant, although low correlation coefficients. This finding is in agreement with our 
findings, with very significant but low correlation coefficients, indicating low linearity in our results. Thus it is expected that in-deed some traits may be correlated to fresh forage yield but in a non-linear way. Furthermore, indirect selection may improve fresh forage yield, but not at the expected level because of a lack of linearity. In other species like cotton, linearity was greater [20].

\section{Conclusions}

Main preconditions of all comparisons were followed and a novel approach of stability index was introduced in all measurements.

Correlations showed a significant relation between fresh forage yield and dry forage yield. Indirect yield improvement may be implemented for improving traits that generally showed high stability indices.

Comparisons between the conventional and low-input farming systems generally showed not to affect stability estimations but revealed varieties that exhibit stable performance in low-input farming systems. (Pigasos) and (Zefyros) displayed stability of performance. Low-input conditions favored forage yield performance, and that is an important agronomic result for farmers. A combination of variety-environment may exhibit a favored performance for some traits, which exhibit considerable stability. This is very useful for farmers, because they may predict with accuracy, i.e., the days to $50 \%$ of flowering, or the performance of dry matter yield, and adapt properly their cultural practice, in the specific environmental conditions. Also, a breeder may be interested in the same traits to predict pollination time and exploit indirect selection for these specific traits.

Taking into account that the interactions found significant, stability analysis was carried out via the AMMI1 and GGE biplots data processing tools. Results showed that based on the productivity expressed by the traits of fresh forage yield and forage dry matter, the most productive and stable varieties were the G5 (Zefyros), followed by the G6 (Pigasos).

In regard to the protein content, the desirable varieties were the G6 (Pigasos) and G2 (Omiros). Regarding the days to $50 \%$ flowering, the varieties were classified into two groups, the early and late, where the most productive was the late variety G5 (Zefyros). Based on the environments' analysis the E1 (Giannitsa) and E4 (Kalambaka) were the most stable over all traits and varieties, while the E2 (Florina) and E3 (Trikala) favored specific variety for each trait. GxE biplot analysis displayed that, for fresh forage yield, (Zefyros) outyielded all other varieties and was found to be in the optimal position.

If fresh forage yield stability is the main aim of both farmers and breeders, then we have to propose certain varieties for specific environments and cultivation systems. For the Trikala area, (Alexandros) is the best variety, for Kalambaka area (Pigasos), and (Tempi) and (Zefyros) for Giannitsa and Florina.

Author Contributions: Conceptualization, V.G. and S.Z.; methodology, V.G. and S.Z.; investigation, V.G. and E.B.; statistical analysis, A.K. and V.G., writing-original draft preparation, V.G. and C.G.I.; writing-review and editing, E.B., A.K. and C.G.I.; visualization, A.K. and V.G.; supervision, S.Z., project administration, S.Z. All authors have read and agreed to the published version of the manuscript.

Funding: This research received no external funding.

Institutional Review Board Statement: Not applicable.

Informed Consent Statement: Not applicable.

Data Availability Statement: The datasets used and/or analyzed during the current study are available from the corresponding author on reasonable request.

Conflicts of Interest: The authors declare no conflict of interest.

\section{References}

1. Firıncıoğlu, H.K.; Erbektas, E.; Doruyol, L.; Mutlu, Z.; Ünal, S.; Karakurt, E. Phenotypic variation of autumn and spring-sown vetch (Vicia sativa ssp.) populations in central Turkey. Span. J. Agric. Res. 2009, 7, 596-606. [CrossRef] 
2. Córdoba, E.M.; Nadal, S.; González-Verdejo, C.I. Common vetch production in Mediterranean Basin. Legume Perspectives. 2015, $10,34-36$.

3. FAO (Food and Agriculture Organization of the United Nations). FAOSTAT Online Database. 2021. Available online: http: //www.fao.org (accessed on 11 April 2021).

4. Fırıncıoğlu, H.K.; Tate, M.; Ünal, S.; Doğruyol, S.; Özcan, İ. A selection strategy for low toxin vetches. Turk. J. Agric. For. 2007, 31, 303-311.

5. Yau, S.K.; Bounejmate, M.; Ryan, J.; Baalbaki, R.; Nassar, A.; Maacaroun, R. Barley-legumes rotations for semi-arid areas of Lebanon. Eur. J. Agron. 2003, 19, 599-610. [CrossRef]

6. Rinnofner, T.; Friedel, J.K.; de Kruijff, R.; Pietsch, G.; Freyer, B. Effect of catch crops on N dynamics and following crops in organic farming. Agron. Sustain. Dev. 2008, 28, 551-558. [CrossRef]

7. Vlachostergios, A.; Lithourgidis, A.; Korkovelos, A.; Baxevanos, D.; Lazaridou, T. Mixing ability of conventionally bred common vetch (Vicia sativa L.) cultivars for grain yield under low-input cultivation. Aust. J. Crop Sci. 2011, 5, 1588-1594.

8. Akdeniz, H.; Koc, A.; Islam, M.S.; El Sabagh, A. Performances of hairy vetch varieties under different locations of mediterranean environment. Fresen. Environ. Bull. 2018, 27, 4263-4269.

9. Georgieva, N.; Nikolova, I.; Delchev, G. Response of spring vetch (Vicia sativa L.) to organic production conditions. Bulg. J. Agric. Sci. 2020, 26, 520-526.

10. Fasoula, V.A. A novel equation paves the way for an everlasting revolution with cultivars characterized by high and stable crop yield and quality. In Proceedings of the 11th National Hellenic Conference in Genetics and Plant Breeding, Orestiada, Greece, 31 October-2 November 2006; pp. 7-14.

11. Fasoula, V.A. Selection of High Yielding Plants Belonging to Entries of High Homeostasis Maximizes Efficiency in Maize Breeding. In Proceedings of the XXI International Eucarpia Conference in Maize and Sorghum Breeding in the Genomics Era, Bergamo, Italy, 21-24 June 2009; p. 29.

12. Papastylianou, P.; Vlachostergios, D.N.; Dordas, C.; Tigka, E.; Papakaloudis, P.; Kargiotidou, A.; Pratsinakis, E.; Koskosidis, A.; Pankou, C.; Kousta, A.; et al. Genotype x environment interaction analysis of faba bean (viciafaba 1.) for biomass and seed yield across different environments. Sustainability 2021, 13, 2586. [CrossRef]

13. Fasahat, P.; Rajabi, A.; Mahmoudi, S.B.; Noghabi, M.A.; Rad, J.M. An overview on the use of stability parameters in plant breeding. Biom. Biostat. Int. J. 2015, 2, 1-11. [CrossRef]

14. Reckling, M.; Ahrends, H.; Chen, T.-W.; Eugster, W.; Hadasch, S.; Knapp, S.; Laidig, F.; Linstädter, A.; Macholdt, J.; Piepho, H.P.; et al. Methods of yield stability analysis in long-term field experiments. A review. Agron. Sustain. Dev. 2021, 41, 27. [CrossRef]

15. Mirosavliević, M.N.; Pržulj, N.; Čanak, P. Analysis of new experimental barley genotype performance for grain yield using AMMI Biplot. Sel. I Semen. 2014, 20, 27-36. [CrossRef]

16. Hongyu, K.; Garcia-Pena, M.; de Araujo, L.B.; dos Santos Dias, C.T. Statistical analysis of yield trials by AMMI analysis of genotype $\times$ environment interaction. Biom. Lett. 2014, 51, 89-102. [CrossRef]

17. Asfaw, A.; Alemayehu, F.; Gurum, F.; Atnaf, M. AMMI and SREG GGE biplot analysis for matching varieties onto soybean production environments in Ethiopia. Sci. Res. Essay 2009, 4, 1322-1330.

18. Fasoulas, A.C. The Honeycomb Methodology of Plant Breeding; Aristoteles University of Thessaloniki: Thessaloniki, Greece, 1988.

19. Fasoula, V.A. Prognostic breeding: A new paradigm for crop improvement. Plant Breed. Rev. 2013, 37, $297-347$.

20. Greveniotis, V.; Sioki, E.; Ipsilandis, C.G. Estimations of fibre trait stability and type of inheritance in cotton. Czech J. Genet. Plant Breed. 2018, 54, 190-192. [CrossRef]

21. Hellenic Agricultural Organization Demeter. Ellinikes Pikilies Ktinotrofikon Psihanthon (Greek Varieties of Forage Legumes); Institute of Industrial and Forage Crops: Larissa, Greece, 2015.

22. Fehr, W.R.; Caviness, C.E. Stages of Soybean Development; Iowa State University: Ames, IA, USA, 1977.

23. AOAC. Official Methods of Analysis, 18th ed.; Association of Official Analytical Chemists: Gaithersburg, MD, USA, 2005.

24. Steel, R.G.D.; Torrie, H.; Dickey, D.A. Principles and Procedures of Statistics. A Biometrical Approach, 3rd ed.; McGraw-Hill: New York, NY, USA, 1997.

25. Koundinya, A.V.V.; Ajeesh, B.R.; Hegde, V.; Sheela, M.N.; Mohan, C.; Asha, K.I. Genetic parameters, stability and selection of cassava genotypes between rainy and water stress conditions using AMMI, WAAS, BLUP and MTSI. Sci. Hortic. 2021, 281, 109949.

26. Phelan, P.; Moloney, A.P.; McGeough, E.J.; Humphreys, J.; Bertilsson, J.; O’Riordan, E.G.; O’Kiely, P. Forage legumes for grazing and conserving in ruminant production systems. Crit. Rev. Plant Sci. 2015, 34, 281-326. [CrossRef]

27. Mikó, P.; Löschenberger, F.; Hiltbrunner, J.; Aebi, R.; Megyeri, M.; Kovács, G.; Molnár-Láng, M.; Vida, G.; Rakszegi, M. Comparison of bread wheat varieties with different breeding origin under organic and low input management. Euphytica 2014, 199, 69-80. [CrossRef]

28. Aydemir, S.K.; Karakoy, T.; Kokten, K.; Nadeem, M.A. Evaluation of yield and yield components of common vetch (Vicia sativa L.) genotypes grown in different locations of Turkey by GGE biplot analysis. Appl. Ecol. Environ. Res. 2019, 17, 15203-15217. [CrossRef]

29. Sayar, M.S. Additive main effects and multiplicative interactions (ammi) analysis for fresh forage yield in common vetch (vicia sativa 1.) genotypes. Agric. For. 2017, 63, 119-127. 
30. Tiryaki, G.Y.; Cil, A.; Tiryaki, I. Revealing seed coat colour variation and their possible association with seed yield parameters in common vetch (Vicia sativa L.). Int. J. Agron. 2016, 2016, 1804108.

31. Greveniotis, V.; Bouloumpasi, E.; Zotis, S.; Korkovelos, A.; Ipsilandis, C.G. Assessment of interactions between yield components of common vetch cultivars in both conventional and low-input cultivation systems. Agriculture 2021, 11, 369. [CrossRef]

32. Sayar, M.S. Path coefficient and correlation analysis between forage yield and its affecting components in common vetch (Vicia sativa L.). Legume Res. 2014, 37, 445-452. [CrossRef] 